\title{
Tracking down the lizards from Gravenhorst's collection at the University of Wrocław: type specimens of Callopistes maculatus Gravenhorst, 1838 and three Liolaemus species rediscovered
}

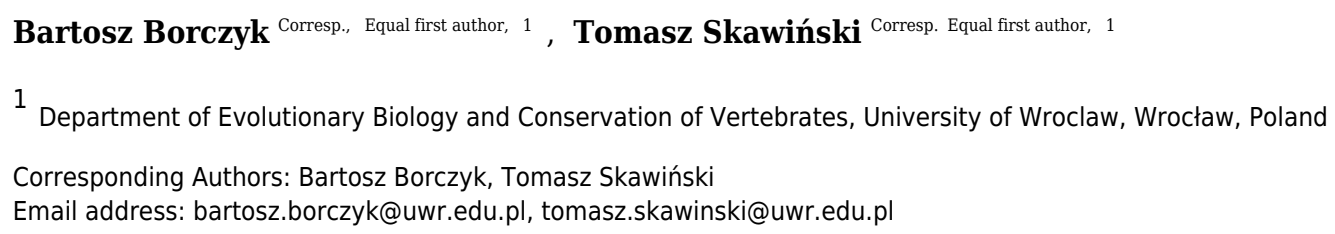

Johann Ludwig Christian Gravenhorst's herpetological collection at the Museum of Natural History, University of Wrocław included numerous important specimens of amphibians and reptiles. The majority, if not the entirety, of this collection has long been thought to be lost. However, we were able to rediscover some type specimens of lizards. The rediscovered specimens include the holotypes of Liolaemus conspersus and $L$. hieroglyphicus, and syntypes of Callopistes maculatus (here designated as the lectotype) and $L$. lineatus (one of which is herein designated as the lectotype). Reexamination of these specimens indicates that previous synonymies proposed for $L$. conspersus and $L$. hieroglyphicus are problematic; furthermore, more complex taxonomic work is needed to resolve this issue. Two rediscovered syntypes of $L$. lineatus differ in several scalation traits and are probably not conspecific. The type specimens of several other species of lizards from Gravenhorst's collection (Liolaemus marmoratus, L. unicolor and two other syntypes of $L$. lineatus, Leiocephalus schreibersii and Chalcides viridanus) were not found and are probably lost. 
1 Tracking down the lizards from Gravenhorst's collection at the

2 University of Wrocław: type specimens of Callopistes

3 maculatus Gravenhorst, 1838 and three Liolaemus species

4 rediscovered

\section{5}

$6 \quad$ Bartosz Borczyk ${ }^{1}$, Tomasz Skawiński ${ }^{1}$

$7{ }^{1}$ Department of Evolutionary Biology and Conservation of Vertebrates, Faculty of Biological Sciences,

8 University of Wroclaw, Wrocław, Poland

10 Corresponding Authors:

11 Bartosz Borczyk ${ }^{1}$

12 Sienkiewicza 21, Wrocław, 50-335 Wrocław, Poland

13 Email address: bartosz.borczyk@uwr.edu.pl

14 Tomasz Skawiński ${ }^{1}$

15 Sienkiewicza 21, Wrocław, 50-335 Wrocław, Poland

16 Email address: tomasz.skawinski@uwr.edu.pl 
17

18

19

20

21

22

23

24

25

26

27

28

29

30

31

32

33

34

35

36

37

38

39

40

41

42

43

44

45

46

47

48

49

50

51

52

53

54

55

56

57

\section{Abstract}

Johann Ludwig Christian Gravenhorst's herpetological collection at the Museum of Natural History, University of Wrocław included numerous important specimens of amphibians and reptiles. The majority, if not the entirety, of this collection has long been thought to be lost. However, we were able to rediscover some type specimens of lizards. The rediscovered specimens include the holotypes of Liolaemus conspersus and L. hieroglyphicus, and syntypes of Callopistes maculatus (here designated as the lectotype) and L. lineatus (one of which is herein designated as the lectotype). Reexamination of these specimens indicates that previous synonymies proposed for L. conspersus and L. hieroglyphicus are problematic; furthermore, more complex taxonomic work is needed to resolve this issue. Two rediscovered syntypes of $L$. lineatus differ in several scalation traits and are probably not conspecific. The type specimens of several other species of lizards from Gravenhorst's collection (Liolaemus marmoratus, L. unicolor and two other syntypes of L. lineatus, Leiocephalus schreibersii and Chalcides viridanus) were not found and are probably lost.

\section{Introduction}

German naturalist Johann Ludwig Christian Gravenhorst (1777-1857) was the founder and first director of the Zoological Museum at the University of Wrocław (Zoologisches Museum der Universität Breslau, currently the Museum of Natural History). His main interests lied in entomology, particularly beetles and, later, ichneumonid wasps (Jałoszyński \& Wanat, 2014). However, like many naturalists of his time, Gravenhorst also had a comprehensive knowledge of many other groups of animals. During his directorship at the museum (from its founding in 1814 to Gravenhorst's death in 1857), he acquired large collections of fishes, amphibians and reptiles from around the world, and published numerous articles on the latter two groups of vertebrates (Jałoszyński \& Wanat, 2014); among them were descriptions of several new species of reptiles (e.g., Gravenhorst, 1838; Gravenhorst, 1851). The type specimens of these forms were usually deposited in the museum in Wrocław; however, at least half of the zoological specimens and $90 \%$ of exhibits were destroyed during the World War II, particularly when the city was sieged and turned into Festung Breslau in 1945 (Wanat \& Pokryszko, 2014). After the war, the identification of some presumably lost specimens was hindered by the fact that - as a part of the "polonisation" of the museum, when the city became part of Poland again - original German labels were replaced by Polish labels (Wiktor, 1997); in the process, errors (e.g., misspellings) were sometimes made (Borczyk, 2013). Some of the important Gravenhorst's zoological specimens were rediscovered after the war (Jałoszyński \& Wanat, 2014), but it was long thought that most or even all of the type specimens of reptiles were also lost at that time (e.g., Dubois \& Ohler, 2000; Nori, Abdala \& Scrocchi, 2010; Etheridge \& Frost, 2012). However, it turned out that some of them survived the war. First, the holotype of Liolaemus lemniscatus Gravenhorst, 1838, was recently redescribed (Borczyk, 2013).

Many species, including all those named by Gravenhorst (except L. lemniscatus) were synonymised by Boulenger (1885). He did not discuss his nomenclatural decisions but they were later accepted, even if only tentatively, by Etheridge \& Espinoza (2000), Etheridge \& Frost 
(2012), Pincheira-Donoso, Scolaro \& Sura (2008) and Abdala \& Quinteros (2014). However, some other species considered junior synonyms by Boulenger (1885), such as L. oxycephalus (Wiegmann, 1834) and L. inconspicuus (Gray, 1845), were later revived from synonymy (Troncoso-Palacios \& Garin, 2013), which warrants a careful re-examination and comparison of these historical specimens. Here we redescribe type specimens of lizards that were rediscovered in the collections of the Museum of Natural History, University of Wrocław. We also discuss taxonomic implications of these findings and provide a catalogue of type specimens of all lizard species named by Gravenhorst.

\section{Material \& Methods}

We focused on describing the morphological characters that were used by previous authors (Ortiz, 1981; Laurent, 1992; Lobo, 2001; Lobo, 2005; Troncoso-Palacios \& Garin, 2013; Troncoso-Palacios et al., 2015a) and considered to be taxonomically informative. The identification and nomenclature of scales follow Etheridge (2000) for liolaemids and Harvey, Ugueto \& Gutberlet Jr (2012) for teiid Callopistes maculatus. The colour pattern description follows the terminology given by Lobo \& Espinoza (1999). Whenever possible, measurements were taken using a digital caliper to the nearest $0.1 \mathrm{~mm}$. When specimens were strongly curled and it was impossible to make a linear measurement, the SVL was measured using a string reaching along the midventral surface from the snout to the vent.

A small amount of muscle tissue was taken from putative holotypes of Liolaemus conspersus and L. hieroglyphicus, and two specimens of Chalcides viridanus collected by Zimmer (other rediscovered specimens were in too poor condition) in an attempt to extract DNA. Unfortunately, these attempts were unsuccessful, so all descriptions and taxonomic assessments were made entirely based on morphology.

The electronic version of this article in Portable Document Format (PDF) will represent a published work according to the International Commission on Zoological Nomenclature (1999) (ICZN), and hence the nomenclatural acts contained in the electronic version are effectively published under that Code from the electronic edition alone. This published work has been registered in ZooBank, the online registration system for the ICZN. The ZooBank LSIDs (Life Science Identifiers) can be resolved and the associated information viewed through any standard web browser by appending the LSID to the prefix http://zoobank.org/. The LSID for this publication is: urn:lsid:zoobank.org:pub:3CDA8E5A-30C8-4847-B4A4-C644595361FC. The online version of this work is archived and available from the following digital repositories: PeerJ, PubMed Central and CLOCKSS.

Abbreviations: MNHNCL - National Museum of Natural History, Santiago de Chile; MNHUW (UWZM) - Museum of Natural History, University of Wrocław; SMF - Senckenberg Forschungsinstitut und Naturmuseum Frankfurt, SVL - snout-vent length. 


\section{6 \\ Results}

97 Extant types

98

99

100

101

102

103

104

105

106

107

108

109

110

111

112

113

114

115

116

117

118

119

120

121

122

123

124

125

126

127

128

129

130

131

132

133

Reptilia Laurenti, 1768

Squamata Oppel, 1811

Teiidae Gray, 1827

\section{Callopistes maculatus Gravenhorst, 1838}

Original name. Callopistes maculatus Gravenhorst, 1838: 744

Type specimens. Two syntypes (described by Gravenhorst, 1838 as "larger" and "smaller" ones) collected by F.S. Scholtz "at the foot of the Cordilleras" (i.e., in the Andean foothills). One of these specimens (MNHUW 1320, male, SVL $141 \mathrm{~mm}$ ) - here identified as the larger one, based on the measurements given by Gravenhorst (1838) - still exists in Wrocław.

Present name. Callopistes maculatus Gravenhorst, 1838

Remarks. Gravenhorst (1838) described the teiid Callopistes maculatus on the basis of two syntypes collected by F.S. Scholtz. Callopistes maculatus is the type species of the genus Callopistes Gravenhorst, 1838, which itself is a type genus of the subfamily Callopistinae Harvey, Ugueto \& Gutberlet Jr, 2012. However, the phylogenetic position of Callopistes is not well understood; Tucker et al. (2016) placed it within Tupinambinae (though as sister to all other tupinambines), thus not recognising Callopistinae, and so did Brizuela \& Albino (2017), though some other authors retained that name (Goicoechea et al., 2016; Quadros, Chafrat \& Zaher, 2018).

The lizard currently known as Callopistes maculatus was first described by Molina (1782) under the name Lacerta palluma. Gravenhorst (1838) misidentified the species, confusing it with a strikingly different iguanian lizard, for which he coined the new generic name Phymaturus. Despite this, Gravenhorst's (1838) application of these two name became universal. Veloso, Núñez \& Cei (2000) proposed the combinations Callopistes palluma (for current C. maculatus) and Phymaturus flagellifer (formerly Centrura flagellifer, currently P. palluma). They attempted to synonymise $C$. maculatus with $C$. palluma and designated a neotype (MNHNCL 2909) for the latter name. However, these proposals were later rejected (Etheridge \& Savage, 2003; International Commission on Zoological Nomenclature, 2005). Callopistes maculatus is a valid name for this teiid lizard and its type specimens are those described by Gravenhorst (1838).

One rediscovered teiid lizard specimen exactly matches the pattern of cephalic scales illustrated by Gravenhorst (1838), so we regard it as the rediscovered syntype. The second specimen from the type series was not illustrated and has not been found. However, according to Gravenhorst's (1838) description, it differed from MNHUW 1320 in several scale counts. Moreover, the type locality of Callopistes maculatus is so vague that it cannot be unambiguously stated that both syntypes were from the same locality. Because two other subspecies of $C$. maculatus occur in Chile (Donoso-Barros, 1960), for the sake of stability, we designate the surviving specimen as the lectotype. 
134 The lectotype is a dry specimen with a broken tail, with the pieces stored together. The right

135

136

137

138

139

140

141

142

143

144

145

146

147

148

149

150

151

152

153

154

155

156

157

158

159

160

161

162

163

164

165

166

167

168

169

170

171

172

173

174 forelimb is also broken, but remains attached to the body (Figs. 1-2). Some aspects of the animal morphology are distorted because of soft tissue shrinkage. However, it seems that the postcloacal buttons are present, which indicates that the lectotype is a male. The dentition is heterodont, with anterior teeth monocuspid, conical or slightly recurved, and posterior teeth with two, sometimes three, cusps. At least two palatal teeth are present on the right pterygoid and at least one tooth is present on the left one. The tongue is deeply bifurcated. The interparietal scale is small, roughly hexagonal and surrounded by five scales, including only two parietals. Twelve scales separate the interparietal from the rostral and eight scales separate the rostral from the frontal (at the midline). The rostral scale is separated from the nasal by one scale and is twice as wide as it is long. There are eight supralabials. The frontal scale is roughly pentagonal, with a strongly asymmetrical posterior border; it is much more concave on its right side. Two rows of long, low lorilabials are present; dorsally to these, there are three loreals. The upper temporal scales are small and oval, while the lower temporal scales are larger, with some of them hexagonal rather than oval. The nasal scale is separated from the canthal, in contact with seven scales. There are eight enlarged supraoculars on the right side and eight on the left side.

The mental scale is wider than it is long. There are 10 infralabials. Five scales contact the second infralabial (including two other infralabials). Posterior to the mental scale, there are four pairs of large chinshields. They are separated from the infralabials by one (anteriorly) or two (posteriorly) rows of sublabials. The first pair of chinshields contact at the midline, but the second and farther pairs are separated by small, oval gular scales (it is impossible to tell the exact number). The whole throat is covered by small, oval or roughly pentagonal, juxtaposed gulars, all about the same size. The interangular sulcus is absent and the intertympanic sulcus is present. Between the throat and the posterior surface of the arms, the scales are also juxtaposed, but larger; some of them are oval, elongated, pentagonal or hexagonal. The whole venter (behind the posterior end of the arms) is covered by large, rectangular, juxtaposed scales. Similar scales, though slightly smaller and imbricate, also cover the entire tail, forming numerous annuli. The dorsal surface of the forelimbs is covered by roughly round, juxtaposed or slightly imbricate scales. The ventral forelimb scales are much smaller, round and juxtaposed. The dorsal hindlimb scales are relatively large, quadrangular, juxtaposed or slightly imbricate. The posterior surface of the thighs is covered by much smaller, round or quadrangular, juxtaposed scales. The ventral thigh scales are roughly rectangular, juxtaposed or minimally imbricate. The ventral shank scales are much larger, rounded and juxtaposed (distally slightly imbricate). The subdigital lamellae on both the fore- and hindlimbs are impossible to count precisely because of the distortion of the specimen (see Table 1 for morphometric data on this and other redescribed lizards).

Most of the original colour pattern is not preserved. The dorsum and flanks are dark brownreddish and the ventral body part is almost uniformly yellowish, with many dark spots on the venter. The pileus is greyish with numerous large, irregular dark spots.

\section{Reptilia Laurenti, 1768}

\section{Squamata Oppel, 1811}




\section{Liolaemidae Frost \& Etheridge, 1989}

\section{Liolaemus conspersus Gravenhorst, 1838}

Original name. Liolaemus conspersus Gravenhorst, 1838: 737

Type specimen. A single specimen (MNHUW 1321, probably male, SVL $83.9 \mathrm{~mm}$ ) collected by F.S. Scholtz in "Cauquenes" (in the current Maule region, Chile). This specimen still exists in Wrocław.

Present name. Liolaemus conspersus Gravenhorst, 1838

Remarks. This species was described by Gravenhorst (1838) on the basis of a single individual from Cauquenes in Chile. It was synonymised with Ptychodeira Fitzingerii (Duméril \& Bibron, 1837) (currently Liolaemus fitzingerii) by Fitzinger (1843) and with L. nigromaculatus (Wiegmann, 1834) by Boulenger (1885). However, Hellmich (1934) was unsure about the synonymy of $L$. conspersus with L. nigromaculatus. The holotype of this species survived the war and was rediscovered during our inspections.

The holotype is a large and robust lizard (Fig. 3). It is probably a male because the musculature associated with the hemipenes seems to be visible under the skin. The specimen is in relatively good condition, and only the left posterior margin of the mouth is damaged (Fig. 4). Also, the left side of the head is much more flattened than the right side. The teeth are highly worn but the posterior teeth are tricuspid.

The number of scales from the rostral to the occiput (the Hellmich index) is 13. The interparietal scale is large (slightly smaller than the parietals), subtriangular, with slightly concave right and slightly convex left margins; it contacts six scales. The frontal scale is single, approximately dumbbell-shaped, with a straight anterior margin and a posterior margin forming an obtuse angle. Five scales separate the rostral from the frontal, and seven scales separate it from the interparietal. The rostral contacts the nasal at a point. Nostrils are directed laterally on the right side and dorsolaterally on the left, probably due to distortion of the specimen. The nasal is separated from the canthal by one scale, and contacts eight scales. There are eight scales between the external nares. There are five flat and long supralabials; the fourth one is located below the eye and has an oblique posterior border. There are five loreals, one of which contacts the subocular. There is one row of seven lorilabials between the supralabials and loreals, four of which contact the subocular. Five infralabials are present; the second one contacts four scales, including two other infralabials (all counts of labial scales were made on the right side because of the damage on the left side of the specimen). There are five enlarged postmental scales (chinshields) on the right side; on the left, there are only four such scales, but the second one clearly originated by the fusion of two scales. The second postmentals are separated from each other by two gular scales. The anteriormost gulars are slightly elongated and juxtaposed, while the others are wider than they are long and imbricate. The auricular scale is not differentiated. Temporal scales have varying shapes: some are subtriangular, some quadrangular, some pentagonal and some hexagonal; all are juxtaposed and unkeeled.There are approximately 73 dorsal scales between the occiput and the anterior surface of the thighs. There are 115 ventral scales between the mental scale and the vent and 77 scales around the midbody. Most of the 
215

216

217

218

219

220

221

222

223

224

225

226

227

228

229

230

231

232

233

234

235

236

237

238

239

240

241

242

243

244

245

246

247

248

249

250

251

252

253

254

255

256

257

ventrals are quadrangular and juxtaposed or subimbricate, but some are pentagonal. The lateral neck scales are rounded or lanceolate, strongly keeled, while the lateral neck scales are small and bead-like. The dorsal scales are larger than the dorsal neck scales but otherwise very similar (Fig. 5A). Interstitial granules are present between the dorsals. The postaxial surface of the forelimbs is covered by relatively large, rounded, imbricate scales. The arm scales lightly are keeled or unkeeled, while the forearm scales are strongly keeled. The preaxial surface of the arm is covered by much smaller, more rounded or bead-like, slightly imbricate scales. The numbers of subdigital lamellae on the left forelimb are as follows: I-11, II-16, III-22, IV-23, V-13; on the right forelimb, they are: I-12, II-18, III-22, IV-22, V-12. The dorsal thigh scales are rounded or lanceolate, imbricate and keeled. The lateral thigh scales are much smaller, rounded or bead-like. The shank scales are relatively large, rounded or lanceolate, very lightly keeled or unkeeled. Postaxial scales on the proximal part of the shank are small, round and slightly imbricate. Both the dorsal and ventral foot scales are rounded or lanceolate and strongly keeled. No precloacal pores are visible (Fig. 5B). The number of subdigital lamellae on the left hindlimb are as follows: I-13, II-18, III-23, IV-31, V-20; on the right hindlimb, they are: I-14, II-19, III-24, IV-30, V-21.

The dorsal colouration is light grey, with the tail being slightly more yellowish. There is no difference in background colour between the vertebral and paravertebral fields. Vertebral, dorsoand ventrolateral stripes are absent. Numerous dark spots or short stripes are faintly visible on almost the entire dorsum and limbs; they are much more visible on the dorsal and lateral aspects of the head. The antehumeral spot cannot be unambiguously identified. Several darker longitudinal stripes are faintly visible on the throat. Apart from that, the ventral colouration is uniformly grey-yellowish.

Liolaemus conspersus does not have a patch of enlarged scales on the posterior surface of the thighs and its fourth supralabial scale is upturned, so its affiliation to the subgenus Eulaemus, and thus synonymy with L. fitzingerii, can be excluded (Laurent, 1992; Lobo, Espinoza \& Quinteros, 2010). Liolaemus conspersus is the only species described by Gravenhorst (1838), for which the subsequent synonimisation by Boulenger (1885) was later put into doubt (Hellmich, 1934), even though most authors accepted it (Etheridge \& Espinoza, 2000; Pincheira-Donoso, Scolaro \& Sura, 2008). Liolaemus nigromaculatus, its presumed senior synonym, and several closely related species, together belonging to the nigromaculatus species group, were redescribed and diagnosed in recent years (Troncoso-Palacios \& Garin, 2013; Troncoso-Palacios et al., 2015a). While the diagnosis of the whole group is difficult to establish (Troncoso-Palacios \& Garin, 2013), it seems that L. conspersus differs from most of its members in at least several characters. The nasal and rostral scales contact at a point in L. conspersus, which differentiates it from L. nigromaculatus, L. atacamensis Müller \& Hellmich, 1933, L. kuhlmanni Müller \& Hellmich, 1933, L. silvai Ortiz, 1989 and L. zapallarensis Müller \& Hellmich, 1933, in which these scales are separated. The second postmental scales are separated by two scales $-\mathrm{a}$ condition that is present only in some L. atacamensis individuals (6 out of 15 , i.e. $40 \%$, in the sample of Troncoso-Palacios et al., 2015a), while in others these scales are separated by just one scale or are in contact. Interstitial granules are present between the dorsal scales in L. conspersus, as in some L. nigromaculatus and L. atacamensis, but unlike L. silvai and L. zapallarensis. Liolaemus conspersus has significantly more scales around the midbody (77) than any of the above-named lizards (48-62; Troncoso-Palacios \& Garin, 2013; Troncoso-Palacios et al., 
258

259

260

261

262

263

264

265

266

267

268

269

270

271

272

273

274

275

276

277

278

279

280

281

282

283

284

285

286

287

288

289

290

291

292

293

294

295

296

297

298

299

300

2015a). The holotype of $L$. conspersus is also larger than all the individuals of L. atacamensis, $L$. kuhlmanni, L. silvai and L. nigromaculatus examined by Troncoso-Palacios \& Garin (2013) and Troncoso-Palacios et al. (2015a), although only slightly larger in the case of the latter species. However, it should also be noted that the method and time of fixation and preservation of the specimen (which are impossible to compare between L. conspersus and specimens studied by Troncoso-Palacios et al., 2015a) might have had an effect on its body measurements, especially the SVL (Vervust, Van Dongen \& Van Damme, 2009).

It is also worth noting that the phylogeny and taxonomic content of the nigromaculatus group are not well established. Mitochondrial DNA analysis by Troncoso-Palacios et al. (2015a) indicates that all these species are closely related, but Panzera et al. (2017), on the basis of analyses using 541 ultra-conserved elements and 44 protein-coding genes, suggested that L. atacamensis is only distantly related to the other named species, even though it is morphologically most similar to $L$. nigromaculatus (Troncoso-Palacios \& Garin, 2013). Therefore, caution must be used when making taxonomic decisions based only on morphological data.

Members of the nigromaculatus group are also geographically separated from Cauquenes, from which the L. conspersus holotype is known. The nearest records are from Valparaíso, which is about 340 kilometres north of Cauquenes (Troncoso-Palacios et al., 2015a). Other Liolaemus species known from Cauquenes [L. chiliensis (Lesson, 1830), L. cyanogaster (Duméril \& Bibron, 1837), L. lemniscatus, L. schroederi Müller \& Hellmich, 1938, L. septentrionalis Pincheira-Donoso \& Núñez, 2005, L. tenuis (Duméril \& Bibron, 1837)] differ from L. conspersus in size, number of scales around the midbody, shape of dorsal scales or a combination of the listed traits (e.g., Pincheira-Donoso \& Núñez, 2005), so their conspecificity can be excluded. However, two species from the Maule Lagoon (located about $80 \mathrm{~km}$ east of Cauquenes) are very similar to L. conspersus in several morphometric and meristic characters. Both Liolaemus buergeri Werner, 1907 and Liolaemus flavipiceus Cei \& Videla, 2003 are of similar size to L. conspersus (maximum SVL of $96.2 \mathrm{~mm}$ and $95.8 \mathrm{~mm}$, respectively; TroncosoPalacios et al., 2015b). The number of dorsal scales in L. buergeri is quite variable - in the sample of Troncoso-Palacios et al. (2015b) it varied between 78 and 91 but Medina, Avila \& Morando (2013) found values higher than 100. The number of ventral scales is between 111 and 125 (Troncoso-Palacios et al., 2015b). Liolaemus flavipiceus has 60-71 dorsal and 93-105 ventral scales (Troncoso-Palacios et al., 2015b). The number of midbody scales is 80-100 in $L$. buergeri and 68-83 in L. flavipiceus (Garin et al., 2013; Troncoso-Palacios et al., 2015b). However, this trait is geographically variable in L. flavipiceus - 16 specimens collected by Troncoso-Palacios et al. (2015b) in Laguna del Maule had 68-78 scales but the single specimen from Paso Pehuenche (holotype) had 83 scales (Garin et al., 2013). In terms of the number of dorsal and ventral scales L. conspersus is more similar to L. buergeri (although it has slightly fewer dorsals) than to $L$. flavipiceus but the converse is true for the number of midbody scales ( $L$. buergeri has more than both $L$. conspersus and L. flavipiceus). It is also worth noting that $L$. flavipiceus is one of the few species in which males do not have precloacal pores (TroncosoPalacios et al., 2015b). If the holotype of L. conspersus is indeed a male, this would suggest its conspecificity with L. flavipiceus. However, at present it is difficult to decide about the potential synonymy of $L$. conspersus with one of these species; further studies are needed to determine whether this is possible to assess. This is important because the name Liolaemus conspersus 
301

302

303

304

305

306

307

308

309

310

311

312

313

314

315

316

317

318

319

320

321

322

323

324

325

326

327

328

329

330

331

332

333

334

335

336

337

338

339

would have priority over both L. buergeri and L. flavipiceus (see also Discussion). At present, we regard it as a species inquirenda, i.e. a species of doubtful identity, needing further investigation (International Commission on Zoological Nomenclature, 1999).

\title{
Liolaemus hieroglyphicus Gravenhorst, 1838
}

\author{
Original name. Liolaemus hieroglyphicus Gravenhorst, 1838: 732
}

Type specimen. A single specimen (MNHUW 1322, probably female, SVL $54.0 \mathrm{~mm}$ ) collected by F.S. Scholtz before 1838 in "Cauquenes" (in the current Maule region, Chile). This specimen still exists in Wrocław.

\section{Present name. Liolaemus hieroglyphicus Gravenhorst, 1838}

Remarks. Gravenhorst (1838) described this species on the basis of a single individual from Cauquenes Province in Chile. It was synonymised with Ptychodeira signifera (Duméril \& Bibron, 1837) (currently Liolaemus signifer) by Fitzinger (1843), with L. olivaceus (currently regarded as a synonym of $L$. chiliensis; Donoso-Barros, 1966) by Tschudi (1845) and with $L$. lemniscatus by Boulenger (1885). Unfortunately, this specimen was not illustrated by Gravenhorst (1838). However, we think that an unlabelled specimen found in the collection is the missing holotype. Our assertion is based on the following reasons: 1) Gravenhorst (1838) stated that $5 / 6$ of the holotype tail is regenerated and a comparable part of the tail is regenerated in the rediscovered specimen; 2) there is an indentation around the neck, which was also noted by Gravenhorst (1838) in L. hieroglyphicus (also in L. unicolor, which is, however, much larger than the specimen described herein); 3) the individual is a similar size and colour to those reported originally by Gravenhorst (1838) and no other specimen in the collection exhibits similar traits.

Immediately after L. hieroglyphicus, Gravenhorst (1838) also described a "variety", which he apparently regarded as an intermediate between L. hieroglyphicus and L. lemniscatus. However, it is unclear whether he intended this form to be a variety of the former species (this is the position taken by Tschudi, 1845) or regarded it as a taxon of a yet unclear taxonomic position. It was based on a smaller individual than the type of $L$. hieroglyphicus. We were not able to locate this specimen. Regardless of these uncertainties, the surviving specimen of L. hieroglyphicus is the only type specimen of the type variety and thus can be regarded as the holotype of that species.

The rediscovered holotype is in very good condition (Figs. 6-7). There are no visible damages, except the indentation around the neck, which was already present at the time of Gravenhorst's work; even the colour pattern is apparently preserved close to the original.

The Hellmich index is 11 . The interparietal scale is hexagonal but with rounded margins, contacts six scales and is much smaller than the parietals. The interparietal is separated by seven scales (at the midline) from the rostral. The frontal scale is hexagonal but with a nearly straight anterior margin, and is separated from the rostral by five scales. The rostral and nasal are in broad contact. The nasal is separated from the canthal by one scale. There are two pairs of 
340

341

342

343

344

345

346

347

348

349

350

351

352

353

354

355

356

357

358

359

360

361

362

363

364

365

366

367

368

369

370

371

372

373

374

375

376

377

378

379

380

381

382

internasals, the first one is in medial contact, the second pair is separated by one scale. Posteriorly, they contact two large, hexagonal frontonasals, also separated medially by one scale. There are five supralabials on both the left and right sides, the fourth one is located below the eye and has an upturned posterior margin. One row of lorilabials separates the supralabials from the loreals. The subocular contacts four lorilabials on the right side but only two on the left side. The loreal region is concave, and contains four loreals on the left and four on the right. The temporal scales are polygonal, some with a rounded posterior margin, juxtaposed or slightly imbricate, not keeled (only a few upper temporals are very lightly keeled). The auricular scale is present, and its ventral border does not reach the auditory meatus midline. There are three enlarged supraoculars, with the first one being the largest. Seven supraciliaries are present. Four infralabials are present on the right side and five on the left side; the second one contacts four scales, including two other infralabials. There are four pairs of enlarged postmental scales (chinshields); the first pair is in contact, and the second pair is separated by two scales. Most gulars are oval, slightly imbricate.

The nuchal and dorsal scales are imbricate, keeled and lanceolate with mucrons (some rounded without mucrons; Fig. 8A). There are 52 dorsal scales, 84 ventral scales and 56 scales around the midbody. Only the tail scales lack keel. The ventral scales are round, juxtaposed or only minimally imbricate. No precloacal pores can be observed (Fig. 8B). The lateral scales are similar to the ventral scales, and they are only much smaller around the limbs, where they are round or bead-like. The forelimb scales are round or lanceolate, imbricate, and only some on the postaxial surface are lightly keeled. The posterior surface of the arms is covered by round, granular, slightly imbricate scales. The numbers of subdigital lamellae on the left forelimb are as follows: I-8, II-12, III-16, IV-16, V-9; on the right forelimb, they are: I-7, II-12, III-15, IV-15, V8. Scales on the hindlimbs are very similar to those on the venter; only on the foot they are much smaller and quadrangular rather than round. The numbers of the subdigital lamellae on the left hindlimb are as follows: I-8, II-13, III-17, IV-22, V-14; on the right hindlimb, they are: I-8, II14, III-18, IV-22, V-13.

The dorsal background colouration is almost uniformly grey. There are numerous short (usually two to three scales long) brown stripes extending from the occiput to the preserved part of the tail, resembling a dotted line running along the spine. Similar stripes are also present in the temporal region. Numerous small brown spots occur on almost the entire pileus (usually several on a single scale), the supralabials and the infralabials. The paravertebral fields are covered by many brown spots, usually one to two scales long and two to four scales wide. Whitish dorsoand ventrolateral lines are present. Between them, the lateral fields are also covered by brownblack spots, which are less numerous but larger than the paravertebral spots. The whole ventral body part is uniformly whitish.

Liolaemus hieroglyphicus does not have a patch of enlarged scales on the posterior surface of the thighs and its fourth supralabial scale is upturned, so its affiliation to the subgenus Eulaemus, and thus synonymy with L. signifer, can be excluded (Laurent, 1992; Lobo, Espinoza \& Quinteros, 2010). It is also not synonymous with L. chiliensis, as it has significantly more scales around the midbody (56 in L. hieroglyphicus, 31-33 in L. chiliensis; Pincheira-Donoso \& Núñez, 2005). The holotype of L. hieroglyphicus shows many similarities to L. lemniscatus, with which it was synonymised (Boulenger, 1885). It is of similar size (SVL), has similar distance between 
383

384

385

386

387

388

389

390

391

392

393

394

395

396

397

398

399

400

401

402

403

404

405

406

407

408

409

410

411

412

413

414

415

416

417

418

419

420

421

422

423

424

425

the axilla and groin and a similar number of ventral scales and scales around the midbody (Martinez et al., 2011; Quinteros, 2012). It shares several scalation traits with the L. lemniscatus holotype (Borczyk, 2013), such as a hexagonal interparietal, much smaller than the parietals; the presence of three enlarged supraorbitals, of which the first one is the largest; contact between the nasal and rostral; separation of the nasal and canthal by one scale; keeled, mucronate, imbricate dorsal scales. However, these two specimens differ significantly in the scalation of the anterior part of the pileus. In L. lemniscatus, there are no single median scales, while in $L$.

hieroglyphicus, two such scales are present, separating the second pair of internasals and both frontonasals. Also, the lateral neck scales in the former species are lanceolate, keeled and imbricate, while in the latter they are granular and unkeeled, being more similar to those in $L$. pseudolemniscatus (Troncoso-Palacios, 2011). Temporal scales are markedly keeled in $L$. lemniscatus (Quinteros, 2012), while in L. hieroglyphicus, most scales lack keel, and only a few upper temporals are very lightly keeled. Liolaemus hieroglyphicus has fewer subdigital lamellae on the fourth toe than the L. lemniscatus specimens listed by Martinez et al. (2011), but more than the holotype of that species (Borczyk, 2013). Liolaemus hieroglyphicus differs from $L$. abdalai (very similar species to L. lemniscatus) by its larger size (the maximum SVL in $L$. abdalai is $50.2 \mathrm{~mm}$ according to Quinteros, 2012). The auricular scale in L. hieroglyphicus is smaller than in members of the L. lemniscatus group, not reaching the auditory meatus midline (Quinteros, 2013). Liolaemus hieroglyphicus differs from L. septentrionalis by having fewer scales around the midbody (56 in L. hieroglyphicus, 63-73 in the latter), more loreal scales (four and two to three, respectively), fewer subdigital lamellae on the fourth toe (22 and 25-28, respectively) and in the shape of the dorsal scales, which are more rounded and do not have a mucron in L. septentrionalis (Pincheira-Donoso \& Núñez, 2005). Liolaemus hieroglyphicus is similar to members of the Liolaemus gravenhorstii group [composed of Liolaemus gravenhorstii (Gray, 1845), L. schroederi and L. cyanogaster (e.g., Quinteros, 2013), but sometimes also including other species such as L. chiliensis (e.g., Portelli \& Quinteros, 2018)]. However, it differs from L. gravenhorstii and L. cyanogaster by having more scales around the midbody (4043 in L. gravenhorstii and 45-50 in L. cyanogaster; Pincheira-Donoso \& Núñez, 2005), and in the shape of the lateral neck scales, which are unkeeled and usually rounded in L. hieroglyphicus, while in L. gravenhorstii they are large, lanceolate, imbricate and strongly keeled and in $L$. cyanogaster, they are small, triangular, imbricate and moderately keeled (Pincheira-Donoso \& Núñez, 2005). It further differs from L. cyanogaster in the shape of the ventral scales, which are imbricate and similar to the dorsals in the latter (Pincheira-Donoso \& Núñez, 2005), while in $L$. hieroglyphicus they are rounded or subquadrangular and only minimally imbricate, as well as in the number of subdigital lamellae on the fourth toe (22 in L. hieroglyphicus, 25-30 in L. cyanogaster; Pincheira-Donoso \& Núñez, 2005). Liolaemus schroederi also has slightly fewer dorsal scales (46-53), but more subdigital lamellae on the fourth toe (24-28). The shape of the ventral scales is very variable in this species - they can be triangular, subtriangular or rounded, as in L. hieroglyphicus. The lateral neck scales are markedly keeled in L. schroederi (PincheiraDonoso \& Núñez, 2005), while in L. hieroglyphicus only the scales located posterodorsally to the auditory meatus have keel. Liolaemus gravenhorstii is also geographically separated from $L$. conspersus, being known primarily from the Metropolitan Region (Pincheira-Donoso \& Núñez, 2005). 
426

427

428

429

430

431

432

433

434

435

436

437

438

439

440

441

442

443

444

445

446

447

448

449

450

451

452

453

454

455

456

457

458

459

460

461

462

Liolaemus hieroglyphicus is not synonymous with L. signifer, L. chiliensis or L. lemniscatus. It is similar to L. cyanogaster and L. schroederi (particularly the latter), but at present cannot be unambiguously synonymised with any of these. We regard it as a species inquirenda, i.e. a species of doubtful identity, needing further investigation (International Commission on Zoological Nomenclature, 1999).

\section{Liolaemus lemniscatus Gravenhorst, 1838}

Original name. Liolaemus lemniscatus Gravenhorst, 1838: 731

Type specimen. A single specimen (MNHUW Re 0027, female) collected by F.S. Scholtz in "Valparaíso", Chile.

Present name. Liolaemus lemniscatus Gravenhorst, 1838

Remarks. The holotype of this species survived the war and was recently redescribed (Borczyk, 2013).

\section{Liolaemus lineatus Gravenhorst, 1838}

Original name. Liolaemus lineatus Gravenhorst, 1838: 723

Type specimens. Four specimens (see also the Remarks section below) of undetermined sex, collected by F.S. Scholtz in "Valparaíso", Chile. Two specimens (MNHUW 1323a, SVL 89.4 mm; MNHUW 1323b, SVL $54.3 \mathrm{~mm}$ ) still exist in Wrocław, and the two others are probably lost.

Present name. Liolaemus nitidus (Wiegmann, 1834)

Remarks. Gravenhorst (1838) distinguished four varieties of this species (one main and three subordinate ones - "Hauptart" and "Abarten" in German). Although the exact number of specimens he had studied is not stated in his article, this suggests that he had at least four specimens in his collection; however, only three individuals are illustrated - one specimen each of the main variety, the second and third varieties. Unfortunately, the first variety was not illustrated. However, in a museum catalogue from before 1907, four specimens are listed, though later note updates it to only two specimens (Fig. 9A). The second catalogue that survived the war (made in 1907; Fig. 9B) lists only three specimens. It is thus possible that some of these lizards were lost even before the war; it cannot be excluded that they had been sent to other institutions but this is not indicated.

All specimens of Liolaemus lineatus were collected in Valparaíso, Chile. The first and second varieties were synonymised with L. olivaceus (Wiegmann, 1834) [currently considered a synonym of L. chiliensis (Lesson, 1830); Pincheira-Donoso \& Núñez, 2005] by Fitzinger (1843), while the third variety was synonymised with L. chiliensis (he did not mention the main variety). Boulenger (1885) synonymised this species (all four varieties) with L. nitidus. Liolaemus lineatus Gravenhorst, 1838 should not be confused with its younger homonym Liolaemus 
463 lineatus Gray, 1845, a species currently regarded as synonymous with Liolaemus nigroviridis 464 Müller \& Hellmich, 1932 (Núñez, 2004).

465

466

467

468

469

470

471

472

473

474

475

476

477

478

479

480

481

482

483

484

485

486

487

488

489

490

491

492

493

494

495

496

497

498

499

500

501

502

503

504

Two individuals, belonging to the second and third varieties, were rediscovered but the specimen representing the unillustrated first variety and a specimen of the main variety are probably lost. Both rediscovered specimens were desiccated and in very poor condition; however, rehydration in $0.5 \% \mathrm{Na}_{3} \mathrm{PO}_{4}$ improved their condition and allowed us to describe many taxonomically informative characters.

The type specimen of the second variety (MNHUW 1323a) is a relatively large and robust lizard with a stout appearance (Figs. 10-11). The specimen is damaged on the right side of the venter, where scales are missing. The teeth are highly worn but the anterior teeth appear to be conical, while the posterior teeth are multicusped. At least one tooth is visible on the left pterygoid and at least one is visible on the right pterygoid. The Hellmich index is 13. The interparietal scale is pentagonal, elongated posteriorly, smaller than the parietals. It contacts six scales and is separated by nine scales from the rostral. The frontal scale is single, large, pentagonal, with almost straight anterior and right margins and a slightly concave left margin; it is separated from the rostral by seven scales. The internarial region is fragmented asymmetrically into six scales. The nasal scale contacts seven scales; it is in broad contact with the rostral and is separated by one scale from the canthal. A roughly rhomboidal scale is located between the prefrontals and frontonasals. There is also a single median scale between the anterior parts of the frontonasals. There are three enlarged supraoculars, with the first one being the largest and the second one being - the smallest. Five supralabials are present on both sides, with the fourth one located below the eye and having an upturned posterior border. The loreal region is concave, containing six scales (eight on the left side), two of which contact the subocular (three on the left side); it is separated from the supralabials by one row of lorilabials (five present on both the left and right sides). Five infralabials are visible on the right side but only four are visible on the left. There are three pairs of enlarged postmental scales (chinshields); the first one is in contact, and the second one is medially separated by two scales. The temporal scales are round or lanceolate, keeled and imbricate. A small patch of much smaller, oval and juxtaposed scales covers the posterior border of the auditory meatus. The number of scales between the posterior border of the auditory meatus and the shoulder is 27 on the left side and 25 on the right side.

The dorsal scales are large, imbricate, strongly keeled and mucronate. There are 33 dorsal scales, 69 ventral scales and 46 scales around the midbody. The tail scales form numerous annuli, which are particularly visible from the ventral side. The ventral tail scales have smaller mucrons. The ventral scales (including the gulars) are also relatively large, lanceolate or rounded (particularly the gulars), imbricate and not keeled. There are 29 gular scales between auditory meatus. The posterior parts of the thighs are covered by much smaller, oval, juxtaposed scales. No precloacal pores are visible. The numbers of subdigital lamellae on the left forelimb are as follows: I-8, II15, III-17, IV-21, V-12; on the right forelimb, they are: I-9, II-15, III-19, IV-20, V-11; on the left hindlimb, they are: I-13, II-17, III-21, IV-25, V-14; on the right hindlimb, they are: I-10, II-15, III-18, IV-25, V-14.

The colour of the head and dorsum is blue-grey. Numerous darker spots are visible on the lateral side of the head; they cover the background colour on the pileus. The ventral body part is almost 
505

506

507

508

509

510

511

512

513

514

515

516

517

518

519

520

521

522

523

524

525

526

527

528

529

530

531

532

533

534

535

536

537

538

539

540

541

542

543

544

545

546

uniformly white-yellow, with the throat covered by several faintly visible darker longitudinal stripes.

The type specimen of the third variety (MNHUW 1323b) is much smaller than MNHUW 1323a (Figs. 12-13). It has minor damage on the venter. The Hellmich index is 13. The interparietal is hexagonal, expanded posteriorly and smaller than the parietals. It contacts six scales. The frontal scale is paired; the right one is hexagonal and elongated, while the left one is shorter and has more rounded margins. Five scales separate the rostral and frontal scales and seven separate the rostral and interparietal. The internarial region is fragmented into six scales, with one scale at the midline. Posteriorly to the postrostrals, there are three scales, arranged in a midline row and separating the frontonasals from each other. The nasal scale is pentagonal, contacts six scales and is separated both from the canthal and the rostral by one scale. There are three enlarged supraoculars, with the first one being the largest. The loreal region is slightly concave and contains six scales, three of which contact the subocular. Five supralabials are present on both the left and right sides; the fourth one is located below the eye and has an upturned posterior margin. One row of lorilabials separates them from the loreals (there are five lorilabials on each side, two contacting the subocular). There are five infralabials on both sides. Three pairs of enlarged postmental scales (chinshields) are present, the first pair in contact, and the second pair separated by two scales. The temporal scales are imbricate, rounded or lanceolate and keeled (only the smallest ones lack keel). The ventral and posterior borders of the auditory meatus are covered by very small, lanceolate, unkeeled scales.

The dorsal and ventral scalation is very similar to the second variety - dorsal scales are imbricate, lanceolate (only the anteriormost nuchal scales are rounded), keeled and mucronate (although the mucrons are slightly smaller), while the ventrals are large, flat, rounded (gulars and ventral neck scales) or lanceolate, imbricate and unkeeled. There are 33 dorsal scales, 64 ventral scales and 43 scales around the midbody. Thirty gulars are present between the auditory meatus. No precloacal pores can be observed. The number of scales between the posterior border of the auditory meatus and the shoulder is 16 on the left side and 18 on the right side. The numbers of subdigital lamellae on the left forelimb are as follows: I-9, II-15, III-18, IV-16, V-12; on the right forelimb, they are: I-9, II-14, III-18, IV-16, V-10; on the left hindlimb, they are: I-10, II-16, III20, IV-26, V-14; on the right hindlimb, they are: I-11, II-15, III-21, IV-25, V-14.

The colouration is very similar to the second variety. The dark stripes on the throat are much more visible in this specimen than in MNHUW 1323a. On the other hand, the spots on the lateral part of the head are better preserved in the type specimen of the second variety; however, this may be an artefact of preservation.

Relationships of Liolaemus nitidus have long been difficult to establish (Pincheira-Donoso \& Núñez, 2005). Most recent morphological studies agree on its affinities to L. robertmertensi and L. chiliensis (Lobo, 2001; Lobo, 2005; Pincheira-Donoso \& Núñez, 2005; Quinteros, 2013). However, molecular analyses indicate completely different phylogenetic position, particularly its close relationship to L. monticola (Troncoso-Palacios et al., 2015; Panzera et al., 2017; TorresPérez et al., 2017). It was always only distantly related to both $L$. robertmertensi and $L$. chiliensis, which were also distantly related to each other, in mitochondrial DNA analyses conducted by Troncoso-Palacios et al. (2015) and combined morphological and nuclear DNA 
547 analyses performed by Portelli \& Quinteros (2018). Thus, it is difficult to evaluate potential 548 synonymy based only on morphological characters. The type specimen of the second variety is 549 indeed similar to L. nitidus in its large size, robustness, presence of lanceolate, keeled and 550 mucronate dorsal scales and imbricate and keeled temporal scales. Moreover, the SVL, the 551 number of scales around the midbody and the subdigital lamellae on the fourth toe are within the 552 range observed in L. nitidus (Pincheira-Donoso \& Núñez, 2005). We failed to note any character 553 differentiating these two forms, so, currently, there seems to be no reason to disprove the 554 synonymy of the second variety with L. nitidus (Boulenger, 1885). However, the third variety 555 differs from the second one (and from L. nitidus; Pincheira-Donoso \& Núñez, 2005) in several 556 characters that have been regarded as taxonomically informative such as the presence of two 557 frontal scales rather than one (also, with a different shape than in L. nitidus) and the contact 558 between the nasal and rostral scales. In all 16 specimens of L. nitidus sampled by Troncoso559 Palacios, the nasal and rostral scales are in contact; this trait is also apparently fixed in $L$. 560 chiliensis (J. Troncoso-Palacios, 2018, pers. comm. - see "peer review history"). The synonymy 561 of the third variety with L. nitidus is more problematic. It is more similar to L. chiliensis, a 562 species with which it was synonymised by Fitzinger (1843), by having a subdivided frontal scale. 563 However, it differs from that species and from L. nitidus by the presence of contact between the 564 rostral and nasal scales (Pincheira-Donoso \& Núñez, 2005).

565 It cannot be excluded that the type specimen of the third variety is a Liolaemus nitidus specimen 566 with several scale anomalies but this is very difficult to test without molecular data. In light of 567 the differences described above, the conspecificity of the type specimens of the second and the 568 third varieties is problematic. According to Gravenhorst's (1838) drawings, the second variety is 569 much more similar to the type variety than to the third one in all traits that could be evaluated 570 (e.g., the presence of the single frontal scale, contact between the rostral and nasal scales, the 571 presence of a small rhomboidal scale between the prefrontals and frontonasals). Therefore, we 572 designate this specimen (MNHUW 1323a) as the lectotype of L. lineatus. Because this name has 573 been considered synonymous with L. nitidus since at least 1885 (Boulenger, 1885), doing so 574 would best serve the nomenclatural stability. The type specimen of the third variety thus 575 becomes the paralectotype, at least until its taxonomic status (potential conspecificity with the 576 lectotype) is resolved.

577

Missing types

\section{Reptilia Laurenti, 1768}

Squamata Oppel, 1811

Liolaemidae Frost \& Etheridge, 1989

\section{Liolaemus marmoratus Gravenhorst, 1838}

Original name. Liolaemus marmoratus Gravenhorst, 1838: 729 
586

587

588

589

590

591

592

593

594

595

596

597

598

599

600

601

602

603

604

605

606

607

608

609

610

611

612

613

614

615

616

617

618

619

Present name. Liolaemus nitidus (Wiegmann, 1834)

Remarks. Liolaemus marmoratus was synonymised with L. nitidus by Boulenger (1885). The name Liolaemus marmoratus was also coined by Burmeister (1861) for the species of an Argentinean lioalemid. However, as it is homonymous with that coined by Gravenhorst (1838), it was later replaced by Liolaemus pseudoanomalus Cei, 1981. We were not able to find the type of L. marmoratus and consider it to be most probably lost.

\section{Liolaemus unicolor Gravenhorst, 1838}

Original name. Liolaemus unicolor Gravenhorst, 1838: 728

Type specimen. A single specimen of unspecified sex, collected by F.S. Scholtz in "a small town in Cauquenes, about 20 German miles south of St. Jago, at the foot of the Cordilleras, where hot springs are present" (about 150 kilometres south of Santiago, Chile). This specimen is probably lost.

Present name. Liolaemus nitidus (Wiegmann, 1834)

Remarks. This species was synonymised with L. nitidus by Boulenger (1885). Unfortunately, it was not illustrated. The morphology of one very poorly preserved Liolaemus specimen is consistent with Gravenhorst's (1838) description of L. unicolor but no unambiguous identification can be made. Therefore, this name must be considered a nomen dubium.

\section{Reptilia Laurenti, 1768}

Squamata Oppel, 1811

\section{Leiocephalidae Frost \& Etheridge, 1989}

\section{Leiocephalus schreibersii (Gravenhorst, 1838)}

Original name. Pristinotus Schreibersii Gravenhorst, 1838: 739

Type specimen. A single specimen of unspecified sex, collected in "St. Domingo" (Santo Domingo, Dominican Republic) by natural history dealer Ludwig Parreys (1796-1879) from Vienna. We did not find this specimen and consider it to be lost.

Present name. Leiocephalus schreibersii (Gravenhorst, 1838)

Remarks. The iguanian lizard Leiocephalus schreibersii was originally described by Gravenhorst under the name Pristinotus Schreibersii on the basis of a single individual collected by Parreys in Santo Domingo, Dominican Republic (Gravenhorst, 1838). The holotype has long been thought to be lost (e.g., Pregill, 1992) and we were also unable to locate it in the collection. Recently, a neotype (SMF 26228) has been designated for this species (Köhler, Rodríguez Bobadilla \& Hedges, 2016). 
Squamata Oppel, 1811

\section{Chalcides viridanus (Gravenhorst, 1851)}

Type specimens. Three specimens collected on "Teneriffa" (Tenerife) by a natural history dealer, Bescke; there are several naturalists with this name, so it is unclear whether one of them collected lizards for Gravenhorst. We were not able to locate any of these specimens and consider them to be lost.

Present name. Chalcides viridanus (Gravenhorst, 1851)

631

632

633

634

635

636

637

638

639

640

641

642

643

644

645

646

647

648

649

650

651

\section{2}

653

654

655

656

657

Remarks. This species of scincine skink was described by Gravenhorst (1851) as Gongylus viridanus on the basis of three individuals collected on Tenerife by Bescke. It also occurs on the islands of El Hierro and Gomera and a few smaller islets (Miras, Pérez-Mellado \& MartínezSolano, 2009). Populations inhabiting these three large islands form three separate clades, with lizards from El Hierro and Gomera probably being sister groups (Brown \& Pestano, 1998). The population from Tenerife is not homogenous and exhibits substantial divergence in mitochondrial DNA sequences, resulting in several geographical clusters (Brown, CamposDelgado \& Pestano, 2000; Brown, Woods \& Thorpe, 2017). However, nuclear DNA shows only shallow divergences and a weak geographical pattern (Brown, Woods \& Thorpe, 2017). Recently, J. Mateo (cited by Miras, Pérez-Mellado \& Martínez-Solano, 2009) suggested that $C$. viridanus probably represents a species complex and should possibly be split. Thus, a detailed description of the syntypes of this species would be useful for potential future works on its taxonomy. Unfortunately, we were unable to locate these specimens in the collection. Two wellpreserved individuals collected on Tenerife by Zimmer in 1906 have been rediscovered (MNHUW uncatalogued; Fig. 14) and one of them could become the neotype. However, we refrain from making such a designation, because no molecular data could be obtained from any of these specimens. We recommend that a potential future neotype designation in $C$. viridanus should involve specimen from a well-defined area (more precise than just "Tenerife"), preferably also with molecular data, especially mitochondrial DNA, because there are several mitochondrial clades within this species.

\section{Discussion}

Natural history museums play a crucial role in the study of biodiversity. Redescriptions of historical specimens, especially name-bearing ones, housed in these locations may have important implications for taxonomy and the nomenclature of many taxa (e.g., Ohler \& Dubois, 2016), to some extent because many of the museum specimens are incorrectly identified and labelled (Goodwin et al., 2015). Such historical specimens served as the basis not only for recent 
658

659

660

661

662

663

664

665

666

667

668

669

670

671

672

673

674

675

676

677

678

679

680

681

682

683

684

685

686

687

688

689

690

691

\section{2}

693

694

695

696

redescriptions of important, name-bearing specimens (e.g., Bucklitsch et al., 2012; Borczyk, 2013; Mecke et al., 2016), but also for descriptions of species that are new to science, hitherto unrecognised (e.g., Böhme et al., 2015), and revalidations of species from synonymy (e.g., Espinoza, Lobo \& Etheridge, 2011). The latter point may be especially important for diverse, species-rich groups such as Liolaemus, with an often controversial taxonomy (Lobo, Espinoza \& Quinteros, 2010; Troncoso-Palacios et al., 2019).

\section{Implications for Liolaemus taxonomy}

We decided not to evert hemipenes in the rediscovered Liolaemus specimens because of their fragility which might lead to damaging them. The fact that precloacal pores were not observed in any of the specimens suggests that all of these individuals are females. However, members of the subgenus Liolaemus (a group to which all rediscovered lizards belong) tend to have significantly fewer precloacal pores than do members of Eulaemus (Laurent, 1992) and there are several Liolaemus species in which both females and males completely lack these pores (Lobo, 2001; Pincheira-Donoso \& Scolaro, 2007; Troncoso-Palacios et al., 2015b). Also, the 'taphonomical' factor must be taken into consideration, i.e., all the processes acting on a specimen after it was collected.

It seems unlikely that the species described by Gravenhorst (1838) represent valid, distinct species, given that they are known from single (L. conspersus, L. hieroglyphicus) or a few (L. lineatus) specimens and no new individuals have been reported for 180 years. However, there are several Liolaemus species that are currently considered valid and are known only from the type locality or only from the type specimen (Meiri et al., 2018), so this fact alone does not argue against their validity. They can be older synonyms of other species (see below) but this is difficult to test without molecular data, in part because of incongruence in the molecular and morphological phylogenies of the group (e.g., Quinteros, 2013; Portelli \& Quinteros, 2018), and in part because interspecific hybridisation is common in Liolaemus lizards (Olave et al., 2018). Matters are further complicated by the fact that the type localities stated for Gravenhorst's taxa are usually very vague: "Cauquenes" for L. conspersus and L. hieroglyphicus and "Valparaíso" for L. lineatus (Gravenhorst, 1838).

To the best of our knowledge, none (except L. lemniscatus) of the Liolaemus nomina coined by Gravenhorst (1838) were used as valid names after 1899; however, this does not make them 'forgotten names', because only senior, and not junior, synonyms can be nomina oblita (Ohler \& Dubois, 2018).

\section{Conclusions}

We rediscovered several important specimens from the Gravenhorst's long thought to be lost herpetological collection at the University of Wrocław: type specimens of the teiid lizard Callopistes maculatus and liolaemids Liolaemus conspersus, L. hieroglyphicus and L. lineatus. Reexamination of the morphology of liolaemids revealed several taxonomically informative 
697

698

699

700

701

702

703

704

705

706

707

708

709

710

711

712

713

714

715

716

717

718

719

720

721

722

723

724

725

726

727

728

729

730

731

732

733

differences between these specimens and their presumed senior synonyms. While the synonymy of L. lineatus and L. nitidus is supported, the same cannot be done for $L$. conspersus and $L$. hieroglyphicus, so we regard them as species inquirendae. Unfortunately, our attempts at molecular analyses were unsuccessful, so resolving the status of these taxa requires further, more complex studies. Nonetheless, the rediscovery of these important specimens underscores the importance of natural history collections, and their proper management and protection, a point that was recently further strengthened by the tragic fire at the National Museum of Brazil in Rio de Janeiro in September 2018.

\section{Acknowledgements}

We thank Jan Kotusz and Tadeusz Stawarczyk (MNHUW) for access to specimens in their care and Agnieszka Pietras-Lebioda for help with molecular analyses. We are grateful to Jaime Troncoso-Palacios, Luis Ceríaco and an anonymous reviewer for detailed and constructive comments that greatly improved the manuscript, and to John Measey for editing.

\section{References}

Abdala CS, Quinteros AS. 2014. Los últimos 30 años de estudios de la familia de lagartijas más diversa de Argentina. Actualización taxonómica y sistemática de Liolaemidae. Cuadernos de herpetología 28:55-82.

Böhme W, Ehrlich K, Milto K, Orlov N, Scholz S. 2015. A new species of desert monitor lizard (Varanidae: Varanus: Psammosaurus) from the Western Zagros region (Iraq, Iran). Russian Journal of Herpetology 22:41-52.

Borczyk B. 2013. Rediscovery and redescription of the holotype of Liolaemus lemniscatus Gravenhorst, 1838 (Reptilia, Squamata, Liolaemidae). ZooKeys 320:97-101 DOI:

10.3897/zookeys.320.5372.

Boulenger GA. 1885. Catalogue of the lizards in the British Museum (Natural History). Volume II. Iguanidae, Xenosauridae, Zonuridae, Anguidae, Anniellidae, Helodermatidae, Varanidae, Xantusiidae, Teiidae, Amphisbaenidae. London: Order of the Trustees, Taylor and Francis DOI: 10.5962/bhl.title.21097.

Brizuela S, Albino AM. 2017. Redescription of the extinct species Callopistes bicuspidatus Chani, 1976 (Squamata, Teiidae). Journal of Herpetology 51:343-354 DOI: 10.1670/16-121.

Brown RP, Campos-Delgado R, Pestano J. 2000. Mitochondrial DNA evolution and population history of the Tenerife skink Chalcides viridanus. Molecular Ecology 9:1061-1067 DOI: 10.1046/j.1365-294x.2000.00962.x.

Brown RP, Pestano J. 1998. Phylogeography of skinks (Chalcides) in the Canary Islands inferred from mitochondrial DNA sequences. Molecular Ecology 7:1183-1191 DOI: 10.1046/j.1365294x.1998.00442.x. 
734 Brown RP, Woods M, Thorpe RS. 2017. Historical volcanism and within-island genetic 735 divergence in the Tenerife skink (Chalcides viridanus). Biological Journal of the Linnean 736 Society 122:166-175 DOI: 10.1093/biolinnean/blx044.

737 Bucklitsch Y, Geissler P, Hartmann T, Doria G, Koch A. 2012. Rediscovery and re-description 738 of the holotype of Lygosoma vittigerum (= Lipinia vittigera) Boulenger, 1894. Acta 739 Herpetologica 7:325-329 DOI: 10.13128/Acta_Herpetol-11037.

740 Burmeister H. 1861. Reise durch die La Plata Staaten mit besonderer Rücksicht auf die

741 physische Beschaffenheit und den Culturzustand der Argentinischen Republik. Ausgeführt in den 742 Jahren 1857, 1858, 1859 und 1860. Halle: H.W. Schmidt.

743 Cei JM. 1981. Liolaemus pseudoanomalus, a substitute name for Liolaemus marmoratus 744 (Burmeister 1861). Journal of Herpetology 15:253-254 DOI: 10.2307/1563394.

745 Donoso-Barros R. 1960. La familia Teiidae en Chile (Squamata, Lacertilia). Revista Chilena de 746 Historia Natural 55:41-54.

747 Donoso-Barros R. 1966. Reptiles de Chile. Santiago: Ediciones de la Universidad de Chile.

748 Dubois A, Ohler A. 2000. Systematics of Fejervarya limnocharis (Gravenhorst, 1829)

749 (Amphibia, Anura, Ranidae) and related species. 1. Nomenclatural status and type-specimens of 750 the nominal species Rana limnocharis Gravenhorst, 1829. Alytes 18:15-50.

751 Duméril AMC, Bibron G. 1837. Erpétologie générale ou histoire naturelle complete des reptiles. 752 Vol. 4. Paris: Roret DOI: 10.5962/bhl.title.45973.

753 Espinoza RE, Lobo F, Etheridge R. 2011. Taxonomic history of the iguanian lizard Liolaemus 754 pictus major Boulenger, with a revalidation of Liolaemus capillitas Hulse. Journal of 755 Herpetology 45:129-133 DOI: 10.1670/10-028.1.

756 Etheridge R. 2000. A review of lizards of the Liolaemus wiegmannii group (Squamata, Iguania, 757 Tropiduridae), and a history of morphological change in the sand-dwelling species.

758 Herpetological Monographs 14:293-352 DOI: 10.2307/1467049.

759 Etheridge R, Espinoza RE. 2000. Taxonomy of the Liolaeminae (Squamata: Iguania:

760 Tropiduridae) and a semi-annotated bibliograpy [bibliography]. Smithsonian Herpetological 761 Information Service 126:1-64 DOI: 10.5479/si.23317515.126.1.

762 Etheridge R, Frost DR. 2012. Catalogue of the Iguania Pleurodonta. Available at 763 http://research.amnh.org/vz/herpetology/catalogue-iguania-pleurodonta (accessed 21 January 764 2019).

765 Etheridge R, Savage JM. 2003. Case 3225. Phymaturus Gravenhorst, 1837 and Lacerta palluma 766 Molina, 1782 (currently Phymaturus palluma; Reptilia, Sauria): proposed conservation of usage 767 of the names by designation of a neotype for Lacerta palluma Molina, 1782. Bulletin of 768 Zoological Nomenclature 60:38-41.

769 Fitzinger L. 1843. Systema reptilium. Fasciculus primus. Amblyglossae. Vienna: Braumüller et 770 Seidel Bibliopolas DOI: 10.5962/bhl.title.4694. 
771 Frost DR, Etheridge R. 1989. A phylogenetic analysis and taxonomy of iguanian lizards

772 (Reptilia: Squamata). The University of Kansas Museum of Natural History Miscellaneous

773 Publication 81:1-65 DOI: 10.5962/bhl.title.16288.

774 Garin CF, Troncoso-Palacios J, Ferri F, Lobos G. 2013. Liolaemus flavipiceus Cei \& Videla,

775 2003: primer registro en Chile y nuevos antecedentes para el taxón (Reptilia, Sauria,

776 Liolaemidae). Cuadernos de herpetología 27:65-69.

777 Goicoechea N, Frost DR, De la Riva I, Pellegrino KCM, Sites Jr J, Rodrigues MT, Padial JM.

778 2016. Molecular systematics of teioid lizards (Teioidea/Gymnophthalmoidea: Squamata) based

779 on the analysis of 48 loci under tree-alignment and similarity-alignment. Cladistics 32:624-671

780 DOI: $10.1111 /$ cla.12150.

781 Goodwin ZA, Harris DJ, Filer D, Wood JRI, Scotland RW. 2015. Widespread mistaken identity

782 in tropical plant collections. Current Biology 25:R1066-R1067 DOI: 10.1016/j.cub.2015.10.002.

783 Gravenhorst JLC. 1838. Beiträge zur genauern Kenntniss einiger Eidechsengattungen. Nova Acta

784 Physico-Medica Academiae Caesareae Leopoldino-Carolinae Naturae Curiosorum 18(2):712-

785784.

786 Gravenhorst JLC. 1851. Über die im Zoologischen Museum der Universität Breslau befindlichen

787 Wirtelschleichen (Pseudosaura), Krüppelfüssler (Brachypoda), und einige andere, denselben

788 verwandte Reptilien aus den Zünften der Schleichen und Dickzüngler. Nova Acta Physico-

789 Medica Academiae Caesareae Leopoldino-Carolinae Naturae Curiosorum 23(1):291-394 DOI:

790 10.5962/bhl.title.12638.

791 Gray JE. 1827. A synopsis of the genera of Saurian reptiles, in which some new genera are

792 indicated, and the others reviewed by actual examination. Philosophical Magazine, Series 2

793 2:54-58 DOI: 10.1080/14786442708675620.

794 Gray JE. 1845. Catalogue of the specimens of lizards in the collection of the British Museum.

795 London: Order of the Trustees DOI: 10.5962/bhl.title.5499.

796 Harvey MB, Ugueto GN, Gutberlet Jr RL. 2012. Review of teiid morphology with a revised

797 taxonomy and phylogeny of the Teiidae (Lepidosauria: Squamata). Zootaxa 3459:1-156.

798 Hellmich W. 1934. Die Eidechsen Chiles, insbesondere die Gattung Liolaemus, nach den

799 Sammlungen Goetsch-Hellmich. Abhandlungen der Bayerischen Akademie der Wissenschaften,

800 Mathematisch-naturwissenschaftliche Abteilung, Neue Folge 24:1-143.

801 International Commission on Zoological Nomenclature. 1999. International code of zoological

802 nomenclature. London: International Trust for Zoological Nomenclature DOI:

803 10.5962/bhl.title.50608.

804 International Commission on Zoological Nomenclature. 2005. Opinion 2118 (Case 3225).

805 Phymaturus Gravenhorst, 1837 and Lacerta palluma Molina, 1782 (currently Phymaturus

806 palluma, Reptilia, Sauria): usage of the names conserved by the designation of a neotype for

807 Lacerta palluma Molina, 1782. Bulletin of Zoological Nomenclature 62:116-117. 
808 Jałoszyński P, Wanat M. 2014. Johann Ludwig Christian Gravenhorst, the first director of the 809 Museum of Natural History, University of Wrocław, and his collection of Ichneumonidae. Genus $810 \quad 25: 583-599$.

811 Köhler G, Rodríguez Bobadilla MJ, Hedges SB. 2016. A new dune-dwelling lizard of the genus 812 Leiocephalus (Iguania, Leiocephalidae) from the Dominican Republic. Zootaxa 4121(5):517813532 DOI: 10.11646/zootaxa.4121.5.2.

814 Laurent RF. 1992. On some overlooked species of the genus Liolaemus Wiegmann (Reptilia 815 Tropiduridae) from Peru. Breviora 494:1-33.

816 Laurenti JN. 1768. Specimen medicum, exhibens synopsin reptilium emendatam cum 817 experimentis circa venena et antidota reptilium Austriacorum. Vienna: Johann Thomas von 818 Trattner DOI: 10.5962/bhl.title.5108.

819 Lesson RP. 1830. Voyage autour du monde, exécuté par ordre du Roi, sur La Corvette de Sa 820 Majesté, la Coquille, pendant les années 1822, 1823, 1824, et 1825. Vol. II. Paris: Arthus 821 Bertrand DOI: 10.5962/bhl.title.57936.

822 Lobo F. 2001. A phylogenetic analysis of lizards of the Liolaemus chiliensis group (Iguania:

823 Tropiduridae). Herpetological Journal 11:137-150.

824 Lobo F. 2005. Las relaciones filogéneticas dentro del grupo chiliensis (Iguania: Liolaemidae: 825 Liolaemus): sumando nuevos caracteres y taxones. Acta zoológica lilloana 49:65-87.

826 Lobo F, Espinoza RE. 1999. Two new cryptic species of Liolaemus (Iguania: Tropiduridae) from 827 northwestern Argentina: resolution of the purported reproductive bimodality of Liolaemus 828 alticolor. Copeia 1999:122-140 DOI: 10.2307/1447393.

829 Lobo F, Espinoza RE, Quinteros S. 2010. A critical review and systematic discussion of recent 830 classification proposals for liolaemid lizards. Zootaxa 2549:1-30.

831 Martinez LE, Avila LJ, Perez CHF, Perez DR, Sites Jr JW, Morando M. 2011. A new species of 832 Liolaemus (Squamata, Iguania, Liolaemini) endemic to the Auca Mahuida volcano, northwestern 833 Patagonia, Argentina. Zootaxa 3010:31-46.

834 Mecke S, Mader F, Kieckbusch M, Kaiser H, Böhme W, Ernst R. 2016. Tracking a syntype of 835 the Australian skink Anomalopus leuckartii (Weinland, 1862): 'lost' treasures in the 836 Senckenberg Natural History Collections Dresden highlight the importance of reassessing and 837 safe-guarding natural history collections. Vertebrate Zoology 66:169-177.

838 Medina CD, Avila LJ, Morando M. 2013. Hacia una taxonomía integral: poniendo a prueba 839 especies candidatas relacionadas a Liolaemus buergeri Werner 1907 (Iguania: Liolaemini) 840 mediante análisis morfológicos. Cuadernos de herpetología 27:27-34.

841 Meiri AS, Bauer AM, Allison A, Castro-Herrera F, Chirio L, Colli G, Das I, Doan TM, Glaw F, 842 Grismer LL, Hoogmoed M, Kraus F, LeBreton M, Meirte D, Nagy ZT, Nogueira CdC, Oliver P, 843 Pauwels OSG, Pincheira-Donoso D, Shea G, Sindaco R, Tallowin OJS, Torres-Carvajal O, Trape 844 J-F, Uetz P, Wagner P, Wang Y, Ziegler T, Roll U. 2018. Extinct, obscure or imaginary: the 
845 lizard species with the smallest range. Diversity and Distributions 24:262-273 DOI:

$846 \quad 10.1111 /$ ddi.12678.

847 Miras JAM, Pérez-Mellado V, Martínez-Solano I. 2009. Chalcides viridanus. The IUCN Red List 848 of Threatened Species 2009:e.T61490A12480456 DOI:

849 10.2305/IUCN.UK.2009.RLTS.T61490A12480456.en.

850 Molina JI. 1782. Saggio sulla storia naturale del Chile. Bologna: Nella Stamperia di S. Tomasso 851 d'Aquino DOI: 10.5962/bhl.title.105203.

852 Müller L, Hellmich W. 1932. Beiträge zur Kenntnis der Herpetofauna Chiles. II. Neue Liolaemus 853 Arten und Rassen aus den Hochanden Chiles. Zoologischer Anzeiger 97:307-329.

854 Müller L, Hellmich W. 1933. Beiträge zur Kenntnis der Herpetofauna Chiles. VII. Der 855 Rassenkreis des Liolaemus nigromaculatus. Zoologischer Anzeiger 103:128-142.

856 Müller L, Hellmich W. 1938. Beiträge zur Kenntnis der Herpetofauna Chiles. XI. Über zwei 857 neue Liolaemus Formen aus der chilenischen Kordillere (Sammlung Schröder). Zoologischer 858 Anzeiger 122:225-232.

859 Nori J, Abdala CS, Scrocchi GJ. 2010. Liolaemus goetschi (Iguania: Liolaemidae): redescription 860 and phylogenetic relationships within the L. boulengeri group. Zootaxa 2440:49-59.

861 Núñez H. 2004. Cambios taxonómicos para la herpetofauna de Argentina, Bolivia y Chile.

862 Noticiario Mensual del Museo Nacional de Historia Natural 353:28-34.

863 Ohler A, Dubois A. 2016. The identity of the South African toad Sclerophrys capensis Tschudi, 8641838 (Amphibia, Anura). PeerJ 4:e1553 DOI: 10.7717/peerj.1553.

865 Ohler A, Dubois A. 2018. Article 23.9 of the Code cannot be used to reject the nomen Hyla 866 quoyi Bory de Saint-Vincent, 1828 as a nomen oblitum. Zoosystema 40:109-121 DOI:

867 10.5252/zoosystema2018v40a6.

868 Olave M, Avila JA, Sites Jr JW, Morando M. 2018. Hybridization could be a common 869 phenomenon within the highly diverse lizard genus Liolaemus. Journal of Evolutionary Biology 870 31:893-903 DOI: $10.1111 /$ jeb.13273.

871 Oppel M. 1811. Die Ordnungen, Familien und Gattungen der Reptilien als Prodrom einer

872 Naturgeschichte derselben. Munich: Joseph Lindauer DOI: 10.5962/bhl.title.4911.

873 Ortiz JC. 1981. Estudio multivariado de las especies de Liolaemus del grupo nigromaculatus

874 (Squamata - Iguanidae). Anales Museo de Historia Natural de Valparaíso 14:247-265.

875 Ortiz JC. 1989. Description de Liolaemus silvai sp. nov. (Sauria, Iguanidae) du « Norte Chico » 876 du Chili. Bulletin du Museum National d'Histoire Naturelle, Section A, Zoologie 11:247-252.

877 Panzera A, Leaché AD, D’Elía G, Victoriano PF. 2017. Phylogenomic analysis of the Chilean 878 clade of Liolaemus lizards (Squamata: Liolaemidae) based on sequence capture data. PeerJ 879 5:e3941 DOI: 10.7717/peerj.3941. 
880 Pincheira-Donoso D, Núñez H. 2005. Las especies chilenas del género Liolaemus Wiegmann, 8811834 (Iguania: Tropiduridae: Liolaeminae). Taxonomía, sistemática y evolución. Publicación 882 Ocasional del Museo Nacional de Historia Natural, Chile 59:7-486.

883 Pincheira-Donoso D, Scolaro JA. 2007. Iguanian species-richness in the Andes of boreal 884 Patagonia: evidence for an additional new Liolaemus lizard from Argentina lacking precloacal 885 glands (Iguania, Liolaeminae). Zootaxa 1452:55-68 DOI: 10.11646/zootaxa.1452.1.4.

886 Pincheira-Donoso D, Scolaro JA, Sura P. 2008. A monographic catalogue on the systematics and 887 phylogeny of the South American iguanian lizard family Liolaemidae (Squamata, Iguania).

888 Zootaxa 1800:1-85.

889 Portelli SN, Quinteros AS. 2018. Phylogeny, time divergence, and historical biogeography of the 890 South American Liolaemus alticolor-bibronii group (Iguania: Liolaemidae). PeerJ 6:e4404 DOI: 891 10.7717/peerj.4404.

892 Pregill GK. 1992. Systematics of the West Indian lizard genus Leiocephalus (Squamata: Iguania: 893 Tropiduridae). The University of Kansas Museum of Natural History Miscellaneous Publication 894 84:1-69 DOI: 10.5962/bhl.title.16285.

895 Quadros AB, Chafrat B, Zaher H. 2018. A new teiid lizard of the genus Callopistes Gravenhorst, 8961838 (Squamata, Teiidae) from the Lower Miocene of Argentina. Journal of Vertebrate 897 Paleontology DOI: 10.1080/02724634.2018.1484754.

898 Quinteros AS. 2012. Taxonomy of the Liolaemus alticolor-bibronii group (Iguania:

899 Liolaemidae), with descriptions of two new species. Herpetologica 68:100-120 DOI:

900 10.1655/HERPETOLOGICA-D-10-00065.1.

901 Quinteros AS. 2013. A morphology-based phylogeny of the Liolaemus alticolor-bibronii group 902 (Iguania: Liolaemidae). Zootaxa 3670(1):1-32 DOI: 10.11646/zootaxa.3670.1.1.

903 Torres-Pérez F, Boric-Bargetto D, Rodríguez-Valenzuela E, Escobar C, Palma RE. 2017.

904 Molecular phylogenetic analyses reveal the importance of taxon sampling in cryptic diversity:

905 Liolaemus nigroviridis and L. monticola (Liolaeminae) as focal species. Revista Chilena de

906 Historia Natural 90:5 DOI: 10.1186/s40693-017-0068-z.

907 Troncoso-Palacios J. 2011. Liolaemus pseudolemniscatus Lamborot and Ortiz, 1990 (Squamata:

908 Liolaemidae): distribution extension in Central Chile. Check List 7:849-851 DOI:

$90910.15560 / 7.6 .849$.

910 Troncoso-Palacios J, Díaz HA, Esquerré D, Urra FA. 2015b. Two new species of the Liolaemus 911 elongatus-kriegi complex (Iguania, Liolaemidae) from Andean highlands of southern Chile. 912 ZooKeys 500:83-109 DOI: 10.3897/zookeys.500.8725.

913 Troncoso-Palacios J, Garin CF. 2013. On the identity of Liolaemus nigromaculatus Wiegmann, 9141834 (Iguania, Liolaemidae) and correction of its type locality. ZooKeys 294:37-56 DOI:

915 10.3897/zookeys.294.4399. 
916 Troncoso-Palacios J, Ruiz De Gamboa M, Langstroth R, Ortiz JC, Labra A. 2019. Without a 917 body of evidence and peer review, taxonomic changes in Liolaemidae and Tropiduridae

918 (Squamata) must be rejected. ZooKeys 813:39-54 DOI: 10.3897/zookeys.813.29164.

919 Troncoso-Palacios J, Schulte JA, Marambio-Alfaro Y, Hiriart D. 2015a. Phenotypic variation, 920 phylogenetic position and new distributional records for the poorly known Liolaemus silvai

921 Ortiz, 1989 (Iguania: Iguanidae: Liolaemini). South American Journal of Herpetology 10:71-81

922 DOI: 10.2994/SAJH-D-14-00007.1.

923 Tschudi JJ. 1845. Reptilium conspectus quae in Republica Peruana reperiuntur et pleraque 924 observata vel collecta sunt in itinere. Archiv für Naturgeschichte 11:150-170 DOI:

925 10.5962/bhl.part.7963.

926 Tucker DB, Colli GR, Giugliano LG, Hedges SB, Hendry CR, Moriarty Lemmon E, Lemmon 927 AR, Sites Jr JW, Pyron RA. 2016. Methodological congruence in phylogenomic analyses with 928 morphological support for teiid lizards (Sauria: Teiidae). Molecular Phylogenetics and Evolution 929 103:75-84 DOI: 10.1016/j.ympev.2016.07.002.

930 Veloso A, Núñez H, Cei JM. 2000. Fixation and description of a neotype for Lacerta palluma 931 Molina 1782 (currently) - (Squamata, Teiidae). Bolletino del Museo Regionale di Scienze 932 Naturali 17:257-268.

933 Vervust B, Van Dongen S, Van Damme R. 2009. The effect of preservation on lizard 934 morphometrics - an experimental study. Amphibia-Reptilia 30:321-329 DOI:

$93510.1163 / 156853809788795209$.

936 Wanat M, Pokryszko BM. 2014. Museum of Natural History, University of Wrocław - 200 years 937 of history in two countries. Genus 25:567-582.

938 Werner E. 1907. Sobre algunos lagartos nuevos clasificados i descritos por el. In: Bürger O, ed. 939 Estudios sobre reptiles chilenos. Anales de la Universidad de Chile 121:149-155 DOI:

$940 \quad 10.5354 / 0717-8883.2015 .32458$.

941 Wiegmann AFA. 1834. Beiträge zur Zoologie, gesammelt auf einer Reise um die Erde. Siebente 942 Abhandlung. Amphibien. Nova Acta Physico-Medica Academiae Caesareae Leopoldino-

943 Carolinae Naturae Curiosorum 17(1):185-268.

944 Wiktor J. 1997. Muzeum Przyrodnicze Uniwersytetu Wrocławskiego. Historia i ludzie, 1814 945 1994. Acta Universitatis Wratislaviensis 1920:1-130. 


\section{Figure 1}

Lectotype of Callopistes maculatus Gravenhorst, 1838 (MNHUW 1320).

(A) Dorsal view. (B) Ventral view. Scale bar $=1 \mathrm{~cm}$.

Photographs by Bartosz Borczyk. 


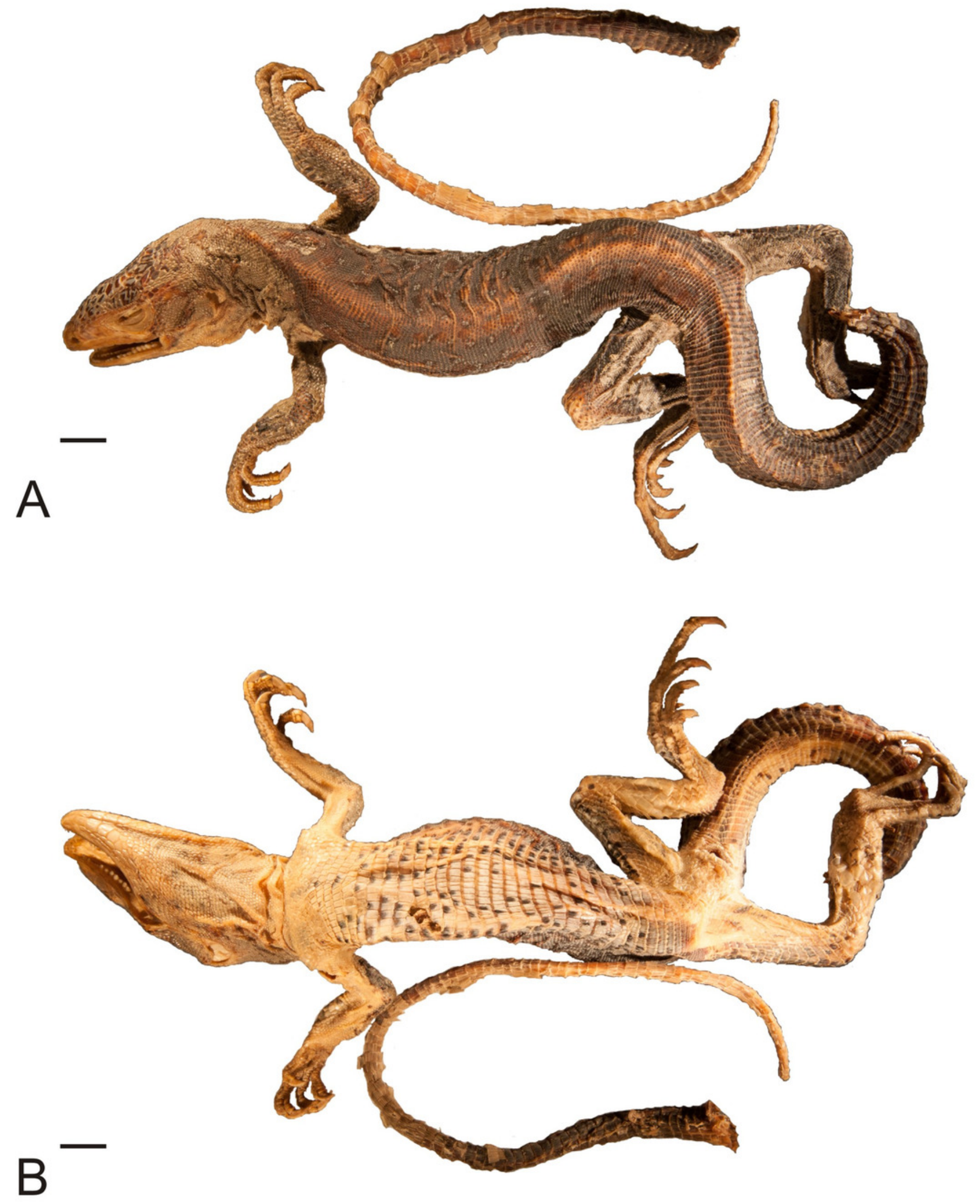




\section{Figure 2}

Head of the lectotype of Callopistes maculatus Gravenhorst, 1838 (MNHUW 1320).

(A) Left lateral view. (B) Right lateral view. (C) Dorsal view. (D) Dorsal view as illustrated by Gravenhorst (1838). Scale bar $=1 \mathrm{~cm}$.

Photographs by Bartosz Borczyk.

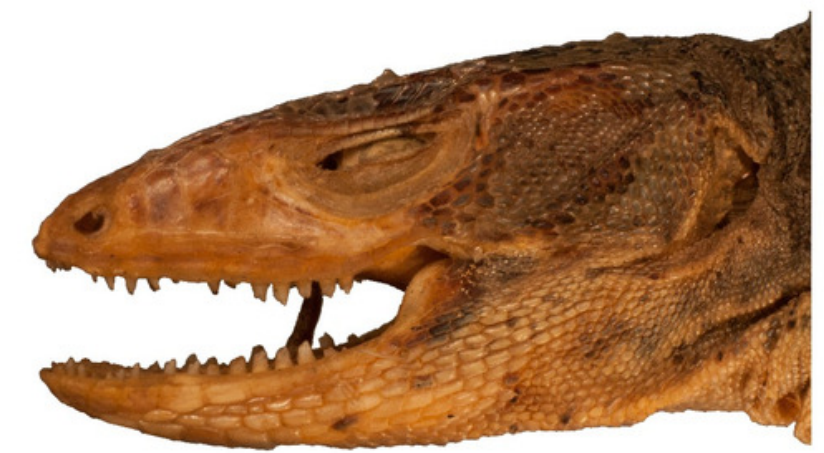

A

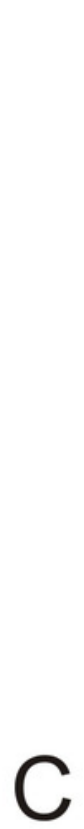

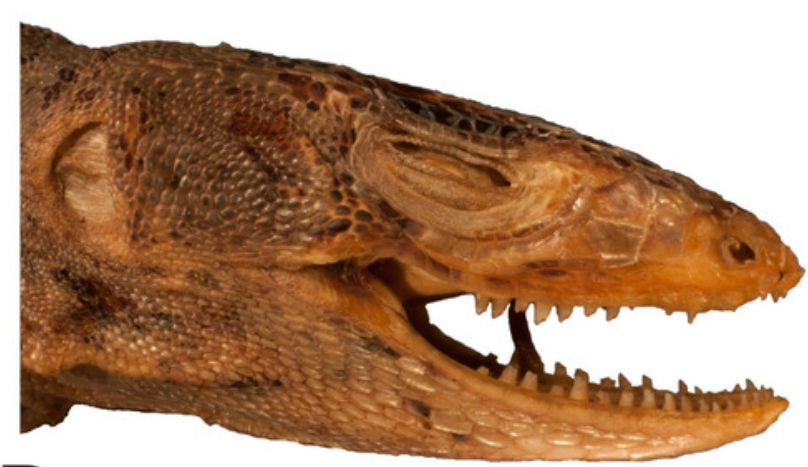

$\mathrm{B}$

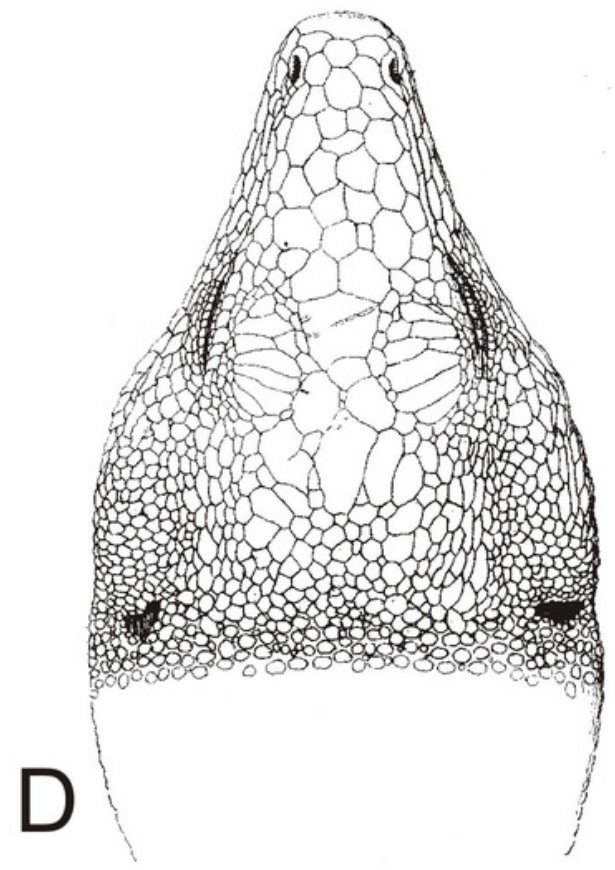


Figure 3

Holotype of Liolaemus conspersus Gravenhorst, 1838 (MNHUW 1321).

(A) Dorsal view. (B) Ventral view. Scale bar $=1 \mathrm{~cm}$.

Photographs by Bartosz Borczyk. 


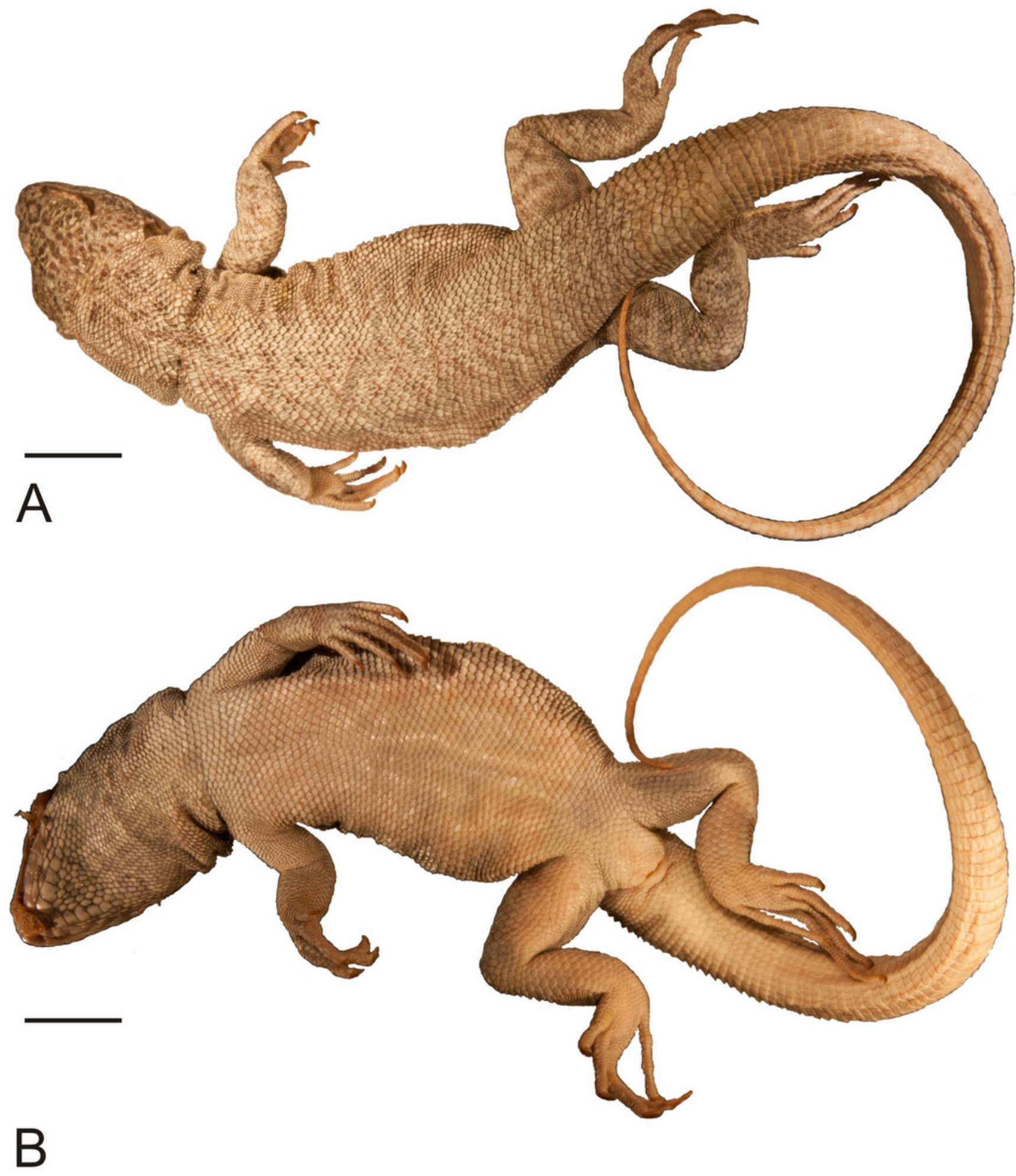




\section{Figure 4}

Head of the holotype of Liolaemus conspersus Gravenhorst, 1838 (MNHUW 1321).

(A) Left lateral view. (B) Right lateral view. (C) Dorsal view. (D) Dorsal view as illustrated by Gravenhorst (1838). Scale bar $=1 \mathrm{~cm}$.

Photographs by Bartosz Borczyk.
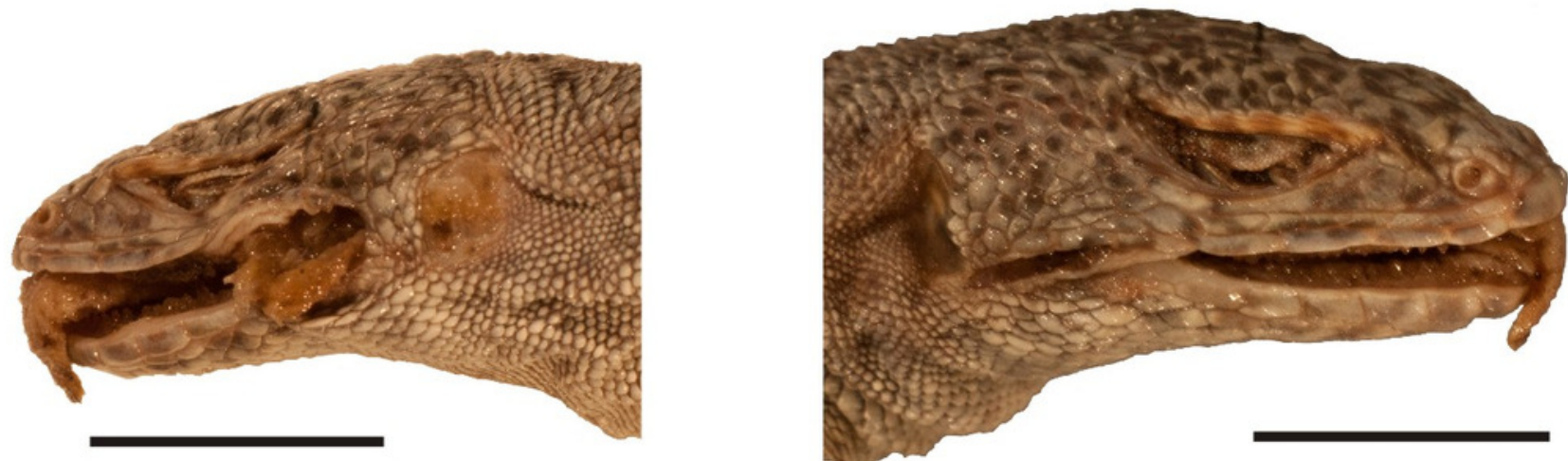

A
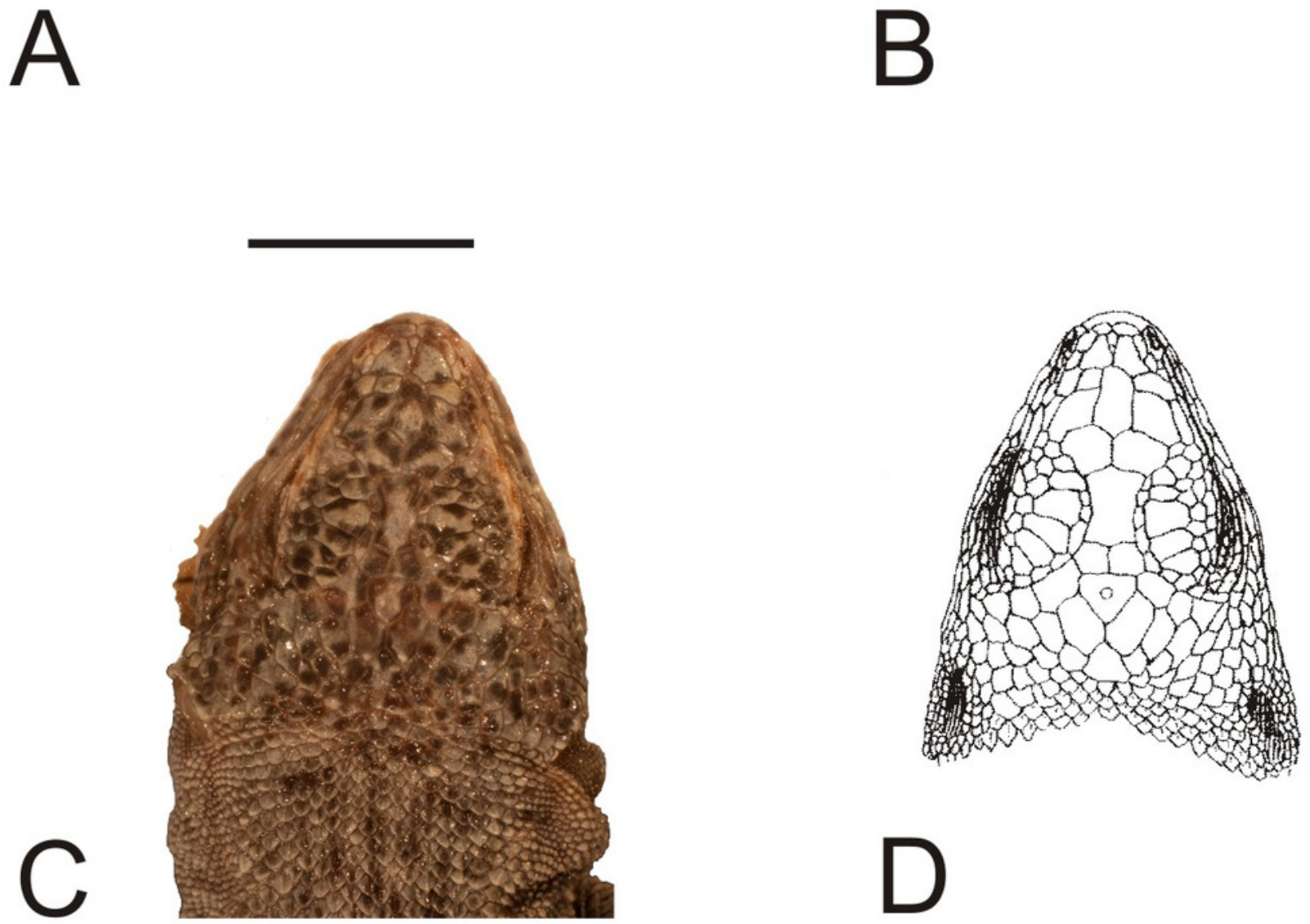


\section{Figure 5}

Morphological details of the Liolaemus conspersus holotype (MNHUW 1321).

(A) Dorsal scales. Some of them are rounded, some are lanceolate, but all with strong keel.

(B) Close-up of the cloacal region. No precloacal pores can be observed. Scale bar $=1 \mathrm{~cm}$.

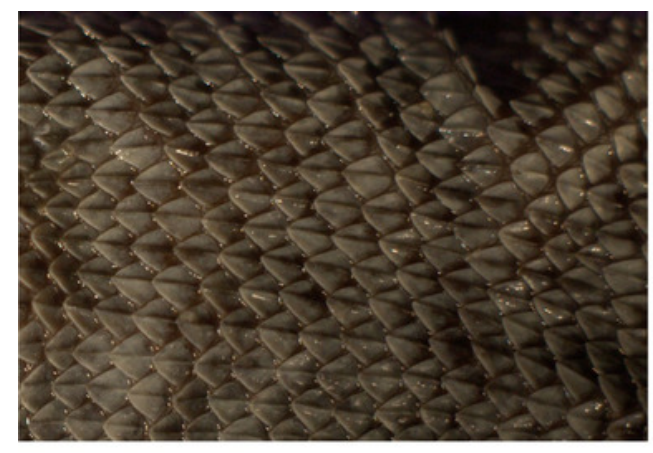

A

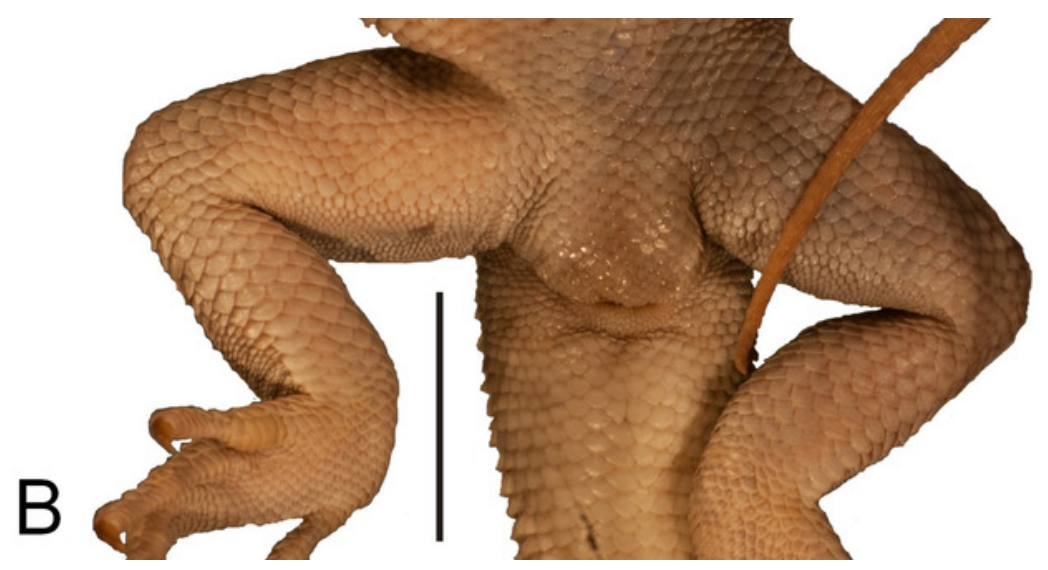


Figure 6

Holotype of Liolaemus hieroglyphicus Gravenhorst, 1838 (MNHUW 1322).

(A) Dorsal view. (B) Ventral view. Scale bar $=1 \mathrm{~cm}$.

Photographs by Bartosz Borczyk.
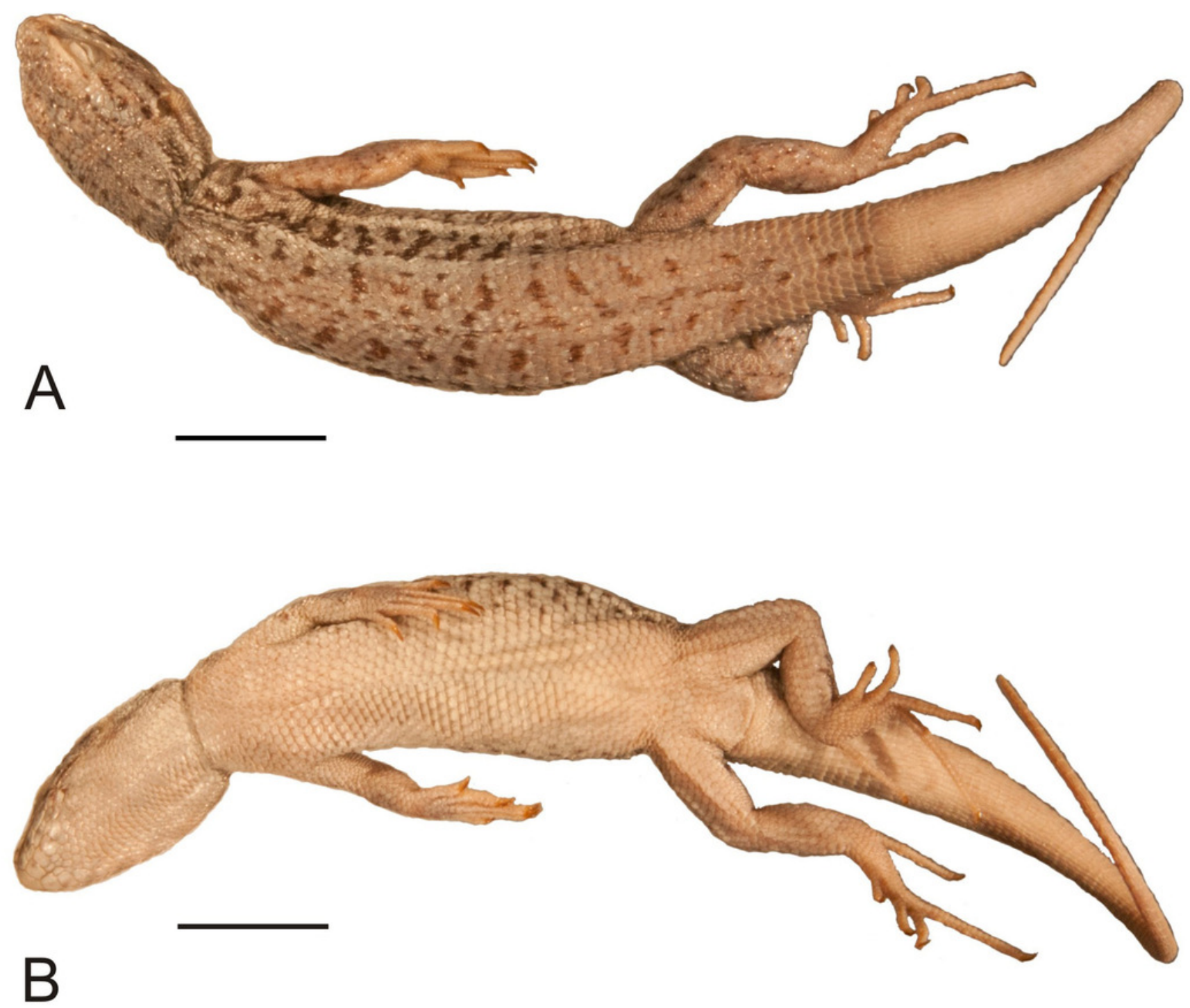


\section{Figure 7}

Head of the holotype of Liolaemus hieroglyphicus Gravenhorst, 1838 (MNHUW 1322).

(A) Left lateral view. (B) Right lateral view. (C) Dorsal view. Scale bar $=1 \mathrm{~cm}$.

Photographs by Bartosz Borczyk.
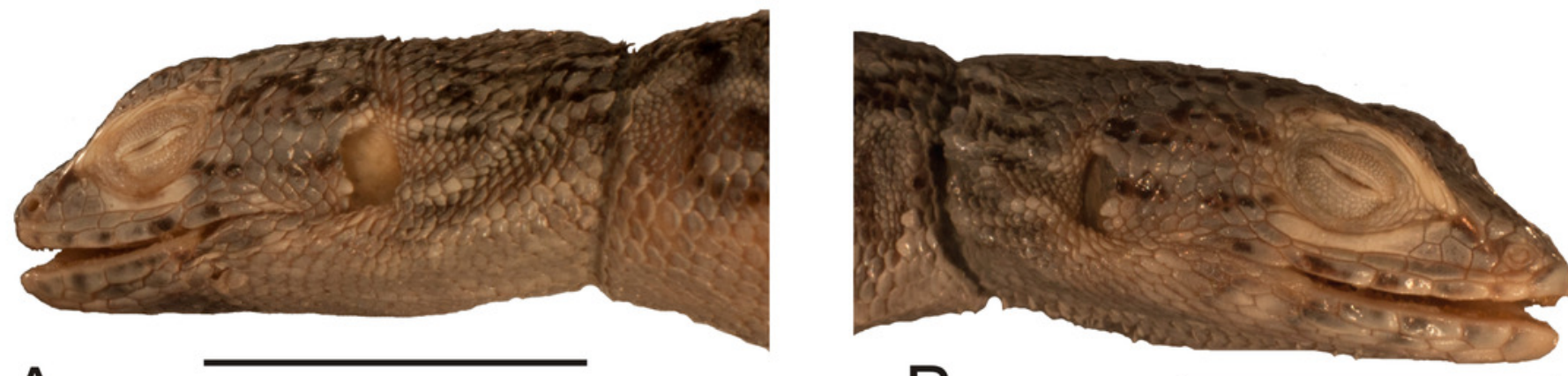

A

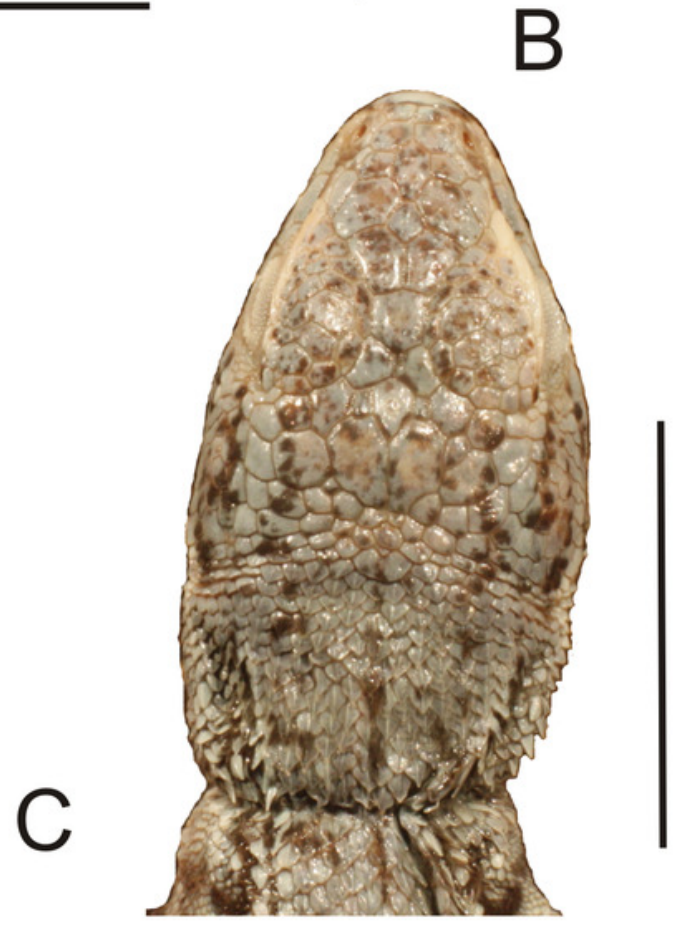


Figure 8

Morphological details of the Liolaemus hieroglyphicus holotype (MNHUW 1322).

(A) Dorsal scales. (B) Close-up of the cloacal region. No precloacal pores can be observed. Scale bar $=1 \mathrm{~cm}$.

Photographs by Bartosz Borczyk.
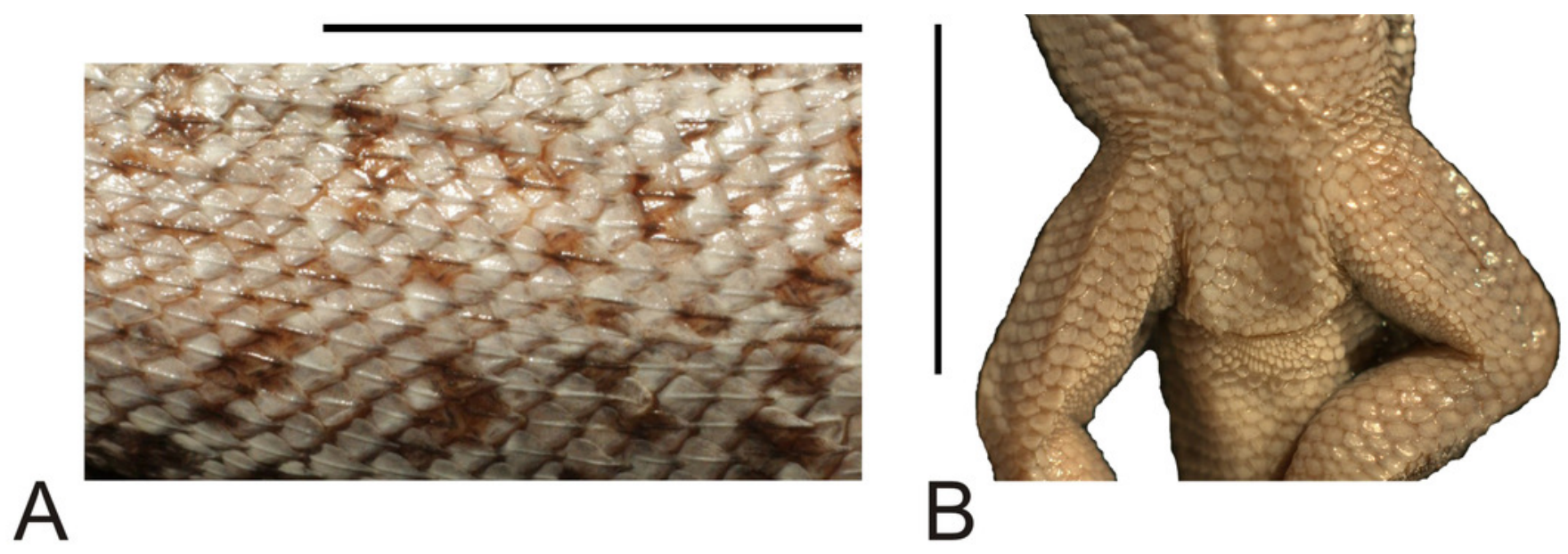
Figure 9

Excerpts from two surviving pre-World War Il catalogues of herpetological specimens in the Museum of Natural History in Wrocław.

\section{(A) Catalogue from before 1907. (B) Catalogue from 1907.}
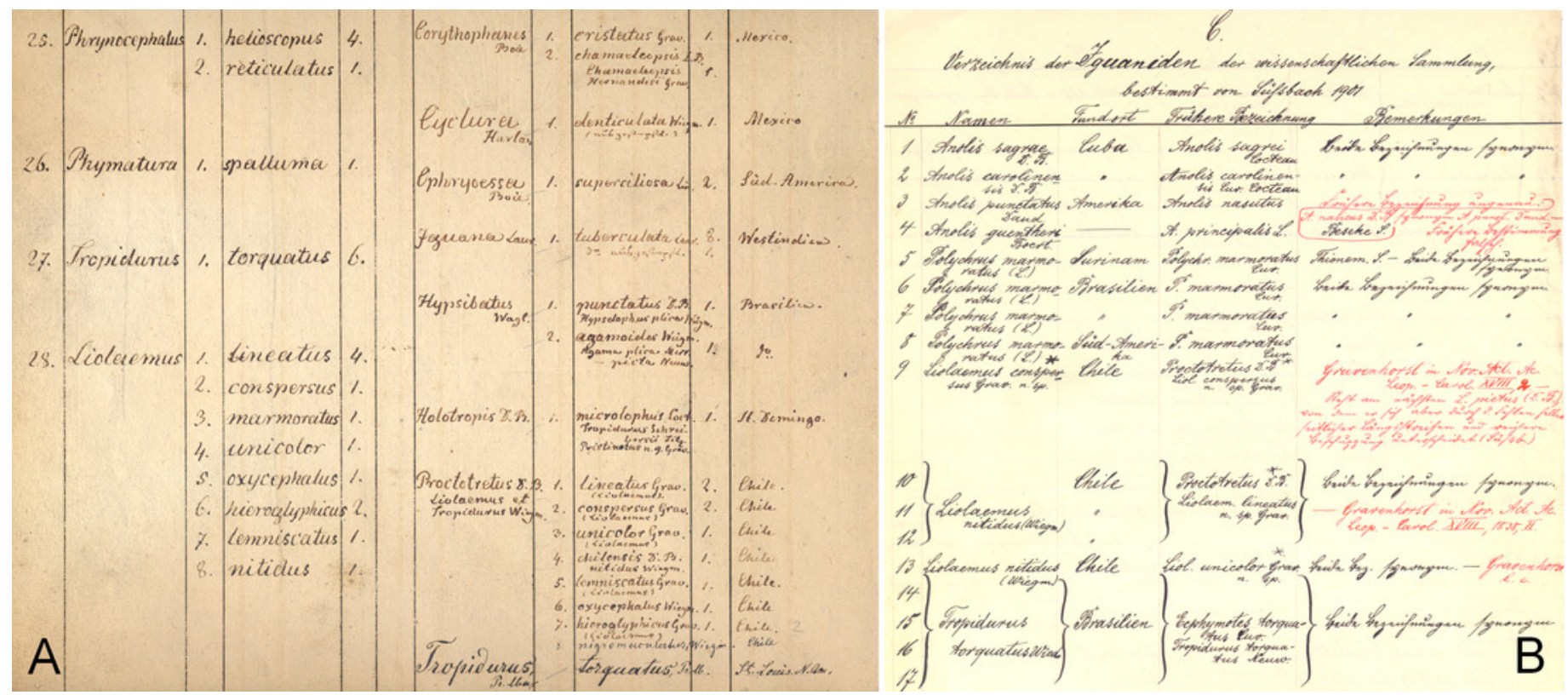


\section{Figure 10}

Lectotype of Liolaemus lineatus Gravenhorst, 1838 (MNHUW 1323a).

(A) Dorsal view. (B) Ventral view. Scale bar $=1 \mathrm{~cm}$.

Photographs by Bartosz Borczyk. 

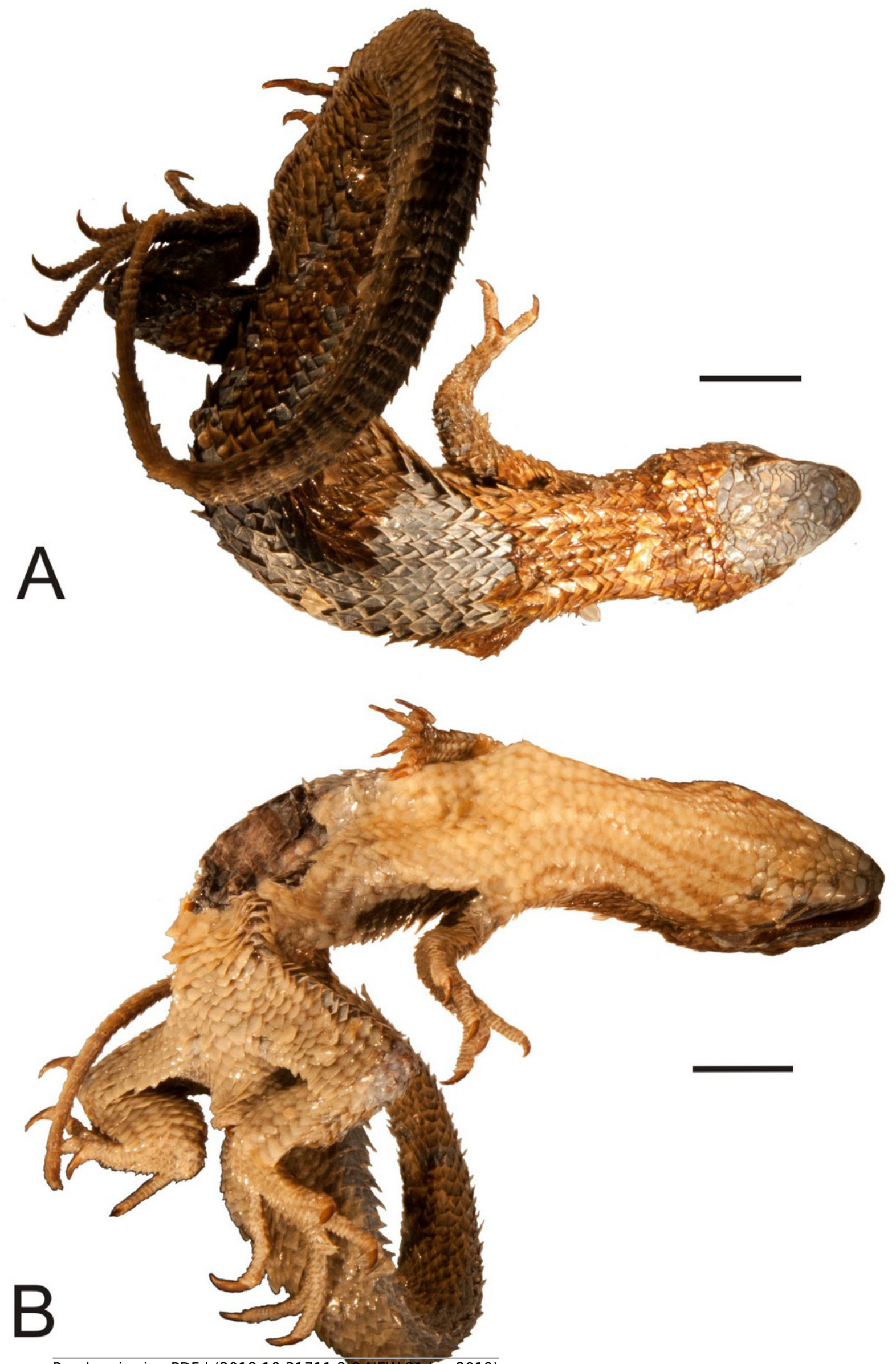

PeerJ reviewing PDF | (2018:10:31711:2:0:NEW 21 Jan 2019) 


\section{Figure 11}

Head of the lectotype of Liolaemus lineatus Gravenhorst, 1838 (MNHUW 1323a).

(A) Left lateral view. (B) Right lateral view. (C) Dorsal view. (D) Dorsal view as illustrated by Gravenhorst (1838). Scale bar $=1 \mathrm{~cm}$.

Photographs by Bartosz Borczyk.
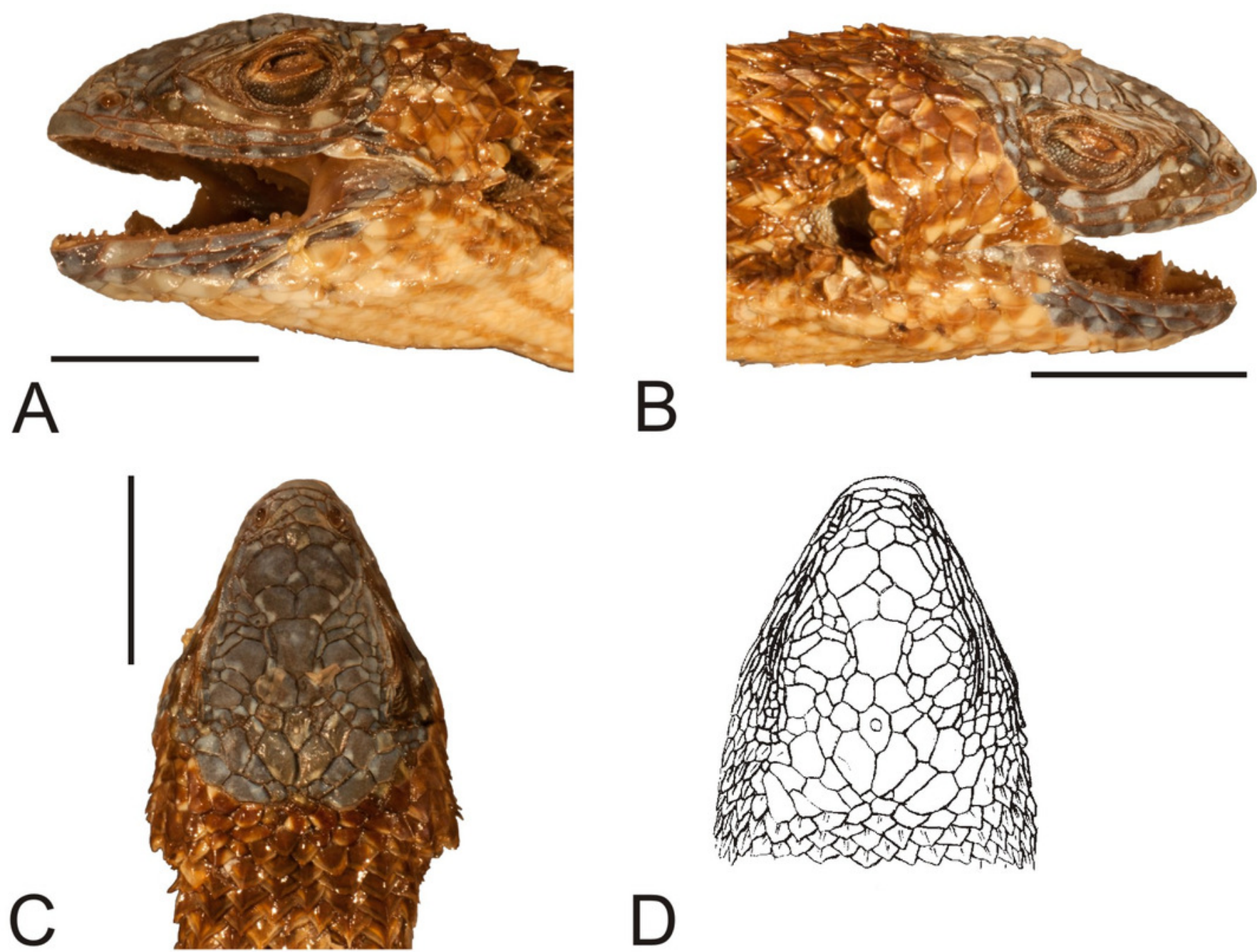


\section{Figure 12}

Paralectotype of Liolaemus lineatus Gravenhorst, 1838 (MNHUW 1323b).

(A) Dorsal view. (B) Ventral view. Scale bar $=1 \mathrm{~cm}$.

Photographs by Bartosz Borczyk. 

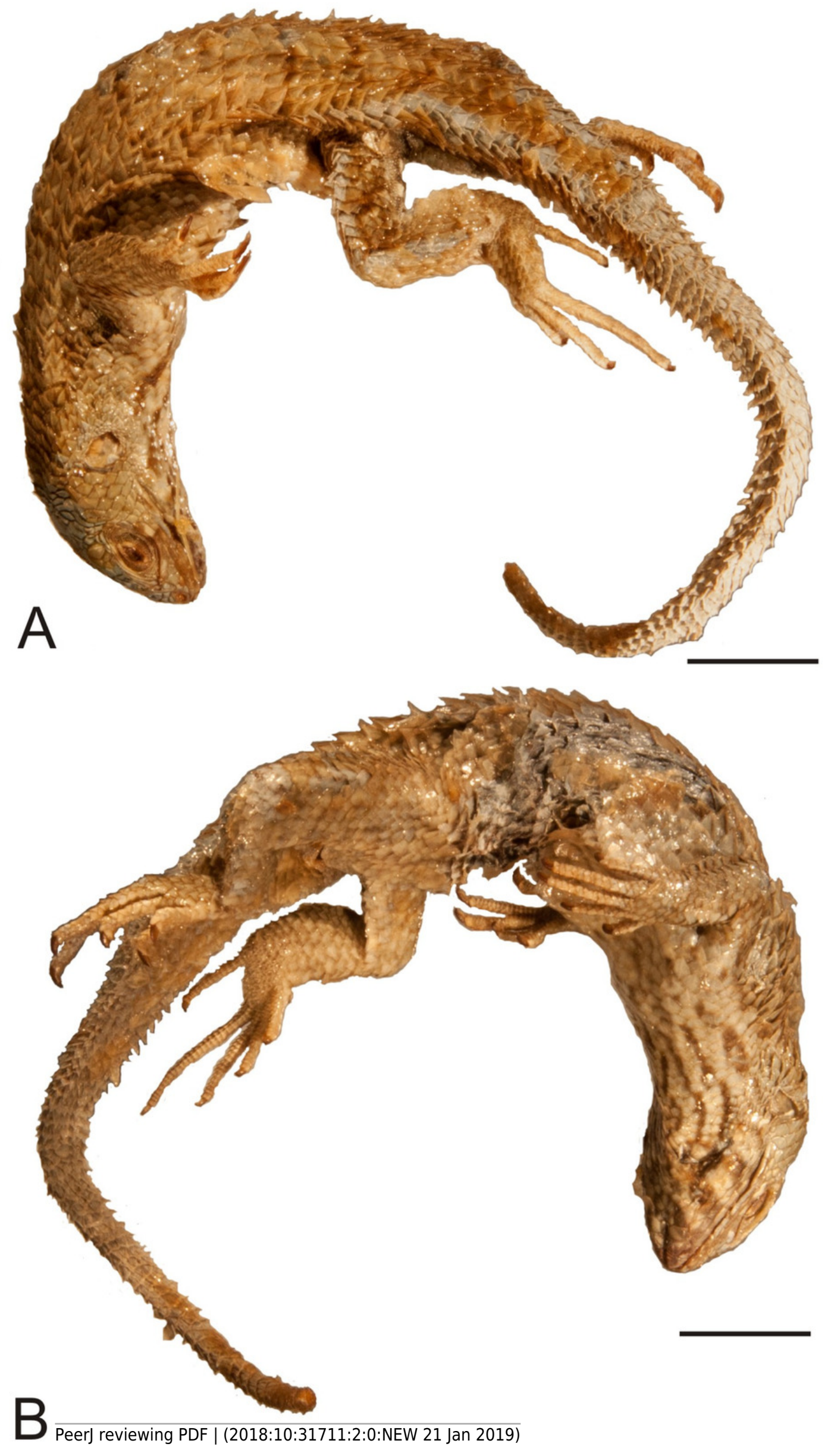


\section{Figure 13}

Head of the paralectotype of Liolaemus lineatus Gravenhorst, 1838 (MNHUW 1323b).

(A) Left lateral view. (B) Right lateral view. (C) Dorsal view. (D) Dorsal view as illustrated by Gravenhorst (1838). Scale bar $=1 \mathrm{~cm}$.

Photographs by Bartosz Borczyk.
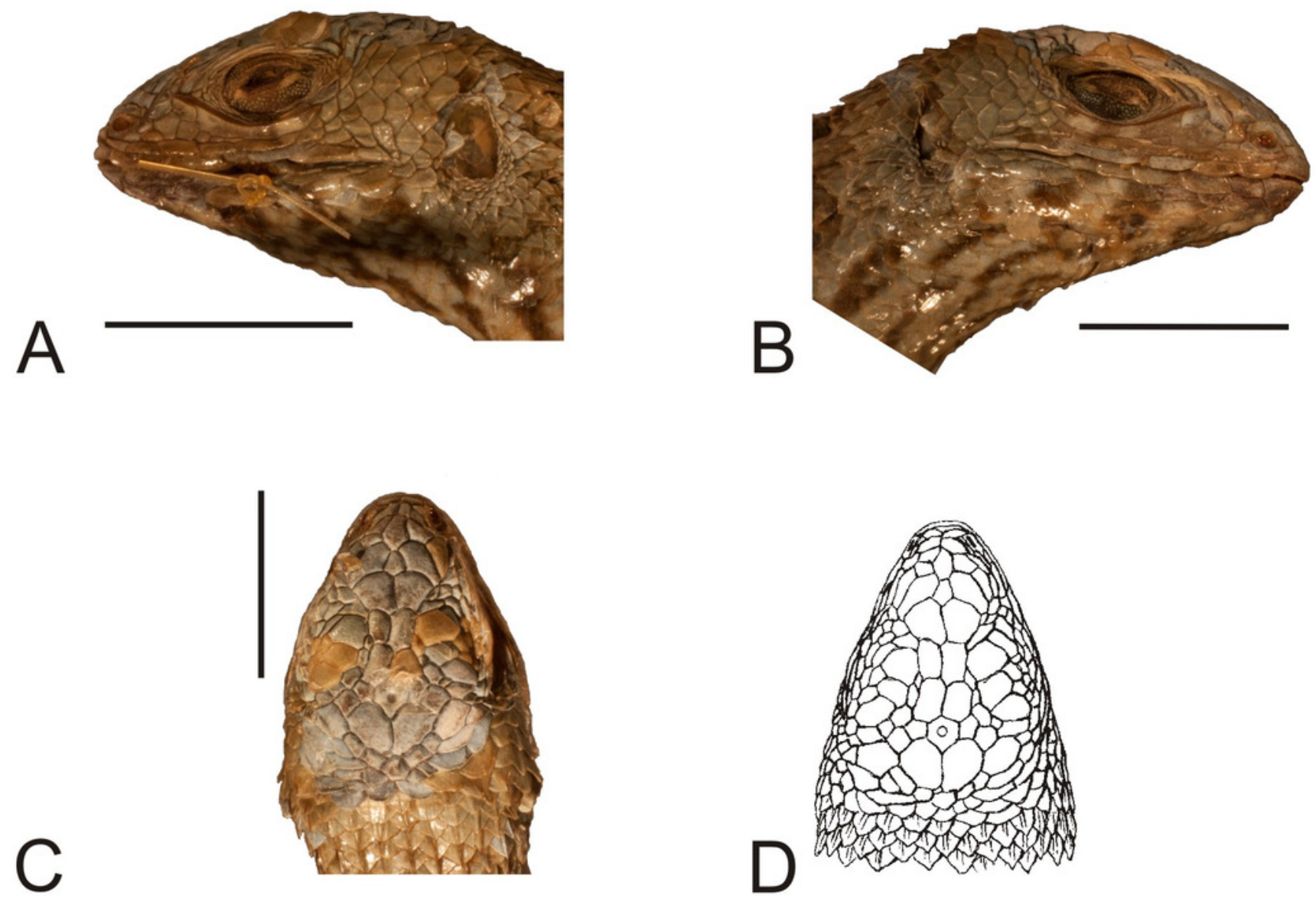


\section{Figure 14}

Two specimens of Chalcides viridanus (Gravenhorst, 1851) (MNHUW uncatalogued) collected by Zimmer on Tenerife.

Scale bar $=1 \mathrm{~cm}$.

Photograph by Bartosz Borczyk. 


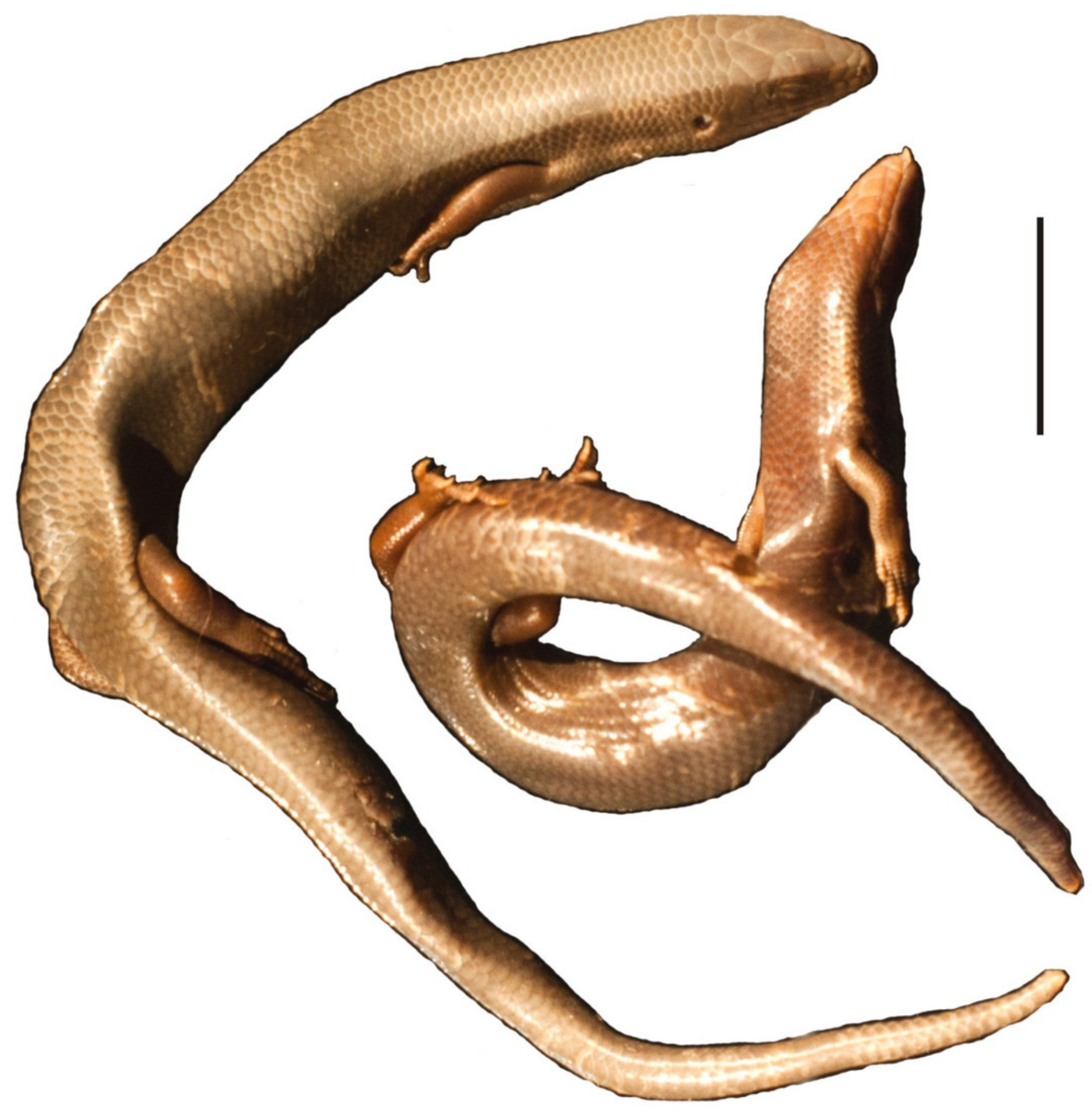




\section{Table $\mathbf{1}$ (on next page)}

Morphometric measurements of the rediscovered lizards.

"R" indicates measurement taken from the right side of the specimen and "L" indicates measurement taken from the left side. Note that not all measurements could be made. 


\begin{tabular}{|c|c|c|c|c|c|}
\hline & $\begin{array}{l}\text { Callopistes } \\
\text { maculatus }\end{array}$ & $\begin{array}{l}\text { Liolaemus } \\
\text { conspersus }\end{array}$ & \begin{tabular}{|l} 
Liolaemus \\
hieroglyphicu \\
s
\end{tabular} & \begin{tabular}{|l|} 
Liolaemus \\
lineatus \\
second variety
\end{tabular} & $\begin{array}{l}\text { Liolaemus } \\
\text { lineatus third } \\
\text { variety }\end{array}$ \\
\hline SVL & 141 & 83.9 & 54.0 & 89.4 & 54.3 \\
\hline Tail length & $\begin{array}{l}292 \text { (the last } \\
203 \mathrm{~mm} \text { are } \\
\text { broken) }\end{array}$ & 137.7 & $\begin{array}{l}11.7 \text { (original } \\
\text { part of the } \\
\text { tail) }\end{array}$ & 123.4 & 76.0 \\
\hline Head length & 38.2 & 21.0 & 13.2 & 22.8 & 18.6 \\
\hline Head width & 20.9 & 16.9 & 9.5 & 16.1 & 13.2 \\
\hline Head height & 19.3 & 9.0 & 6.8 & 12.9 & 11.0 \\
\hline $\begin{array}{l}\text { Axilla-groin } \\
\text { distance }\end{array}$ & 67.0 & 40.5 & 22.6 & - & - \\
\hline $\begin{array}{l}\text { Tail base } \\
\text { width }\end{array}$ & 14.8 & 11.8 & 7.0 & 11.6 & 9.0 \\
\hline $\begin{array}{l}\text { Interorbital } \\
\text { distance } \\
\text { (between } \\
\text { postorbital } \\
\text { semicircles) }\end{array}$ & 4.9 & 1.4 & 1.5 & 3.0 & 2.6 \\
\hline $\begin{array}{l}\text { Eye-auditory } \\
\text { meatus } \\
\text { distance }\end{array}$ & 12.6 & 7.2 & 4.1 & 9.1 & 6.8 \\
\hline $\begin{array}{l}\text { Internarial } \\
\text { distance }\end{array}$ & 4.7 & 3.9 & 2.7 & 3.6 & 3.1 \\
\hline Arm length & $19.1 \mathrm{~L}$ & $11.2 \mathrm{R} / 11.8 \mathrm{~L}$ & $7.4 \mathrm{R} / 6.2 \mathrm{~L}$ & $12.4 \mathrm{R} / 13.1 \mathrm{~L}$ & $11.1 \mathrm{R} / 10.9 \mathrm{~L}$ \\
\hline Thigh length & $33.0 \mathrm{R} / 26.6 \mathrm{~L}$ & $14.2 \mathrm{R} / 16.0 \mathrm{~L}$ & $10.2 \mathrm{R} / 10.1 \mathrm{~L}$ & $15.6 \mathrm{R} / 16.4 \mathrm{~L}$ & $14.7 \mathrm{R} / 14.1 \mathrm{~L}$ \\
\hline Shank length & $31.1 \mathrm{R} / 28.2 \mathrm{~L}$ & $17.9 \mathrm{R} / 17.7 \mathrm{~L}$ & $10.2 \mathrm{R} / 10.1 \mathrm{~L}$ & $16.8 \mathrm{R} / 17.6 \mathrm{~L}$ & $14.4 \mathrm{R} / 14.7 \mathrm{~L}$ \\
\hline Foot length & - & $26.2 \mathrm{R} / 25.4 \mathrm{~L}$ & $16.1 \mathrm{R} / 14.6 \mathrm{~L}$ & $26.1 \mathrm{R} / 24.8 \mathrm{~L}$ & $19.9 \mathrm{R} / 19.0 \mathrm{~L}$ \\
\hline $\begin{array}{l}\text { Subocular } \\
\text { length }\end{array}$ & - & $5.5 \mathrm{R}$ & $4.2 \mathrm{R}$ & $6.1 \mathrm{R}$ & $5.7 \mathrm{R}$ \\
\hline $\begin{array}{l}\text { Preocular } \\
\text { length }\end{array}$ & - & $1.6 \mathrm{R}$ & $0.9 \mathrm{R}$ & $1.4 \mathrm{R}$ & $1.3 \mathrm{R}$ \\
\hline $\begin{array}{l}\text { Rostral } \\
\text { length/width }\end{array}$ & $2.3 / 4.7$ & $1.6 / 3.9$ & $0.8 / 2.6$ & $1.4 / 3.8$ & $0.9 / 3.7$ \\
\hline $\begin{array}{l}\text { Mental } \\
\text { length/width }\end{array}$ & $2.6 / 4.1$ & $2.3 / 4.7$ & $1.5 / 2.7$ & $1.9 / 3.9$ & $1.7 / 3.3$ \\
\hline $\begin{array}{l}\text { Auditory } \\
\text { meatus }\end{array}$ & $6.0 / 3.5 \mathrm{R}$ & $4.1 / 2.5 \mathrm{R}$ & 2.0/1.5 R & $3.5 / 2.8 \mathrm{R}$ & - \\
\hline
\end{tabular}


height/width 1 